\title{
Strategies for successful recombinant expression of disulfide bond-dependent proteins in Escherichia coli
}

\section{Ario de Marco}

\author{
Address: Cogentech, IFOM-IEO Campus for Oncogenomic, via Adamello, 16 - 20139, Milano, Italy
}

Email: Ario de Marco - ario.demarco@ifom-ieo-campus.it

Published: 14 May 2009

Microbial Cell Factories 2009, 8:26 doi:10.1 186/1475-2859-8-26
Received: 2 February 2009

Accepted: 14 May 2009

This article is available from: http://www.microbialcellfactories.com/content/8/I/26

(c) 2009 de Marco; licensee BioMed Central Ltd.

This is an Open Access article distributed under the terms of the Creative Commons Attribution License (http://creativecommons.org/licenses/by/2.0), which permits unrestricted use, distribution, and reproduction in any medium, provided the original work is properly cited.

\begin{abstract}
Bacteria are simple and cost effective hosts for producing recombinant proteins. However, their physiological features may limit their use for obtaining in native form proteins of some specific structural classes, such as for instance polypeptides that undergo extensive post-translational modifications. To some extent, also the production of proteins that depending on disulfide bridges for their stability has been considered difficult in $E$. coli.

Both eukaryotic and prokaryotic organisms keep their cytoplasm reduced and, consequently, disulfide bond formation is impaired in this subcellular compartment. Disulfide bridges can stabilize protein structure and are often present in high abundance in secreted proteins. In eukaryotic cells such bonds are formed in the oxidizing environment of endoplasmic reticulum during the export process. Bacteria do not possess a similar specialized subcellular compartment, but they have both export systems and enzymatic activities aimed at the formation and at the quality control of disulfide bonds in the oxidizing periplasm.

This article reviews the available strategies for exploiting the physiological mechanisms of bactera to produce properly folded disulfide-bonded proteins.
\end{abstract}

\section{Background}

The success of recombinant protein expression in E. coli depends mainly on the capability of avoiding unproductive interactions of newly expressed polypeptides. Such interactions lead to aggregation of folding intermediates instead of yielding native proteins. The efficiency of the process can be increased by favoring conditions that stabilize folding intermediates and promote the formation of mature structure. Several strategies may help in preventing protein aggregation by masking hydrophobic patches on their external surfaces. These include the introduction of chaperone molecules, adding detergents, or co-expressing interacting sub-units of larger complexes. Once the conditions have been optimized for keeping the folding intermediates monodispersed, it becomes crucial to speed up the folding process to reach stable native structures and avoid the accumulation of metastable configurations that remain potentially prone to aggregation. Foldases and isomerases may strongly enhance the folding (Fig 1 ).

The attention of this review will be focused on the technically available solutions to improve the bacterial expression of proteins that rely on disulfide bond formation to reach their native state. Such cys-cys bridges block folding units into stable conformations by linking residues in a covalent manner and their formation is necessary for a protein to achieve its stable tertiary structure.

The equilibrium between reduced and oxidized cysteines is regulated by the redox conditions of each cell compart- 


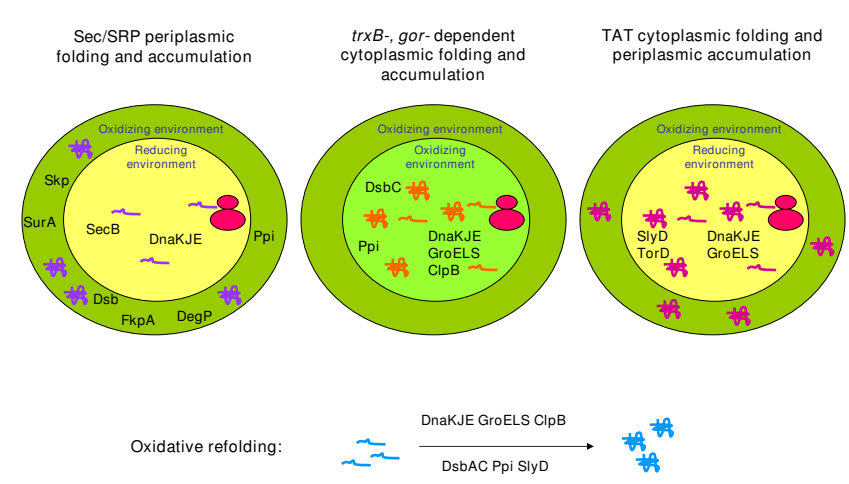

Figure I

Schematic representation of folding pathways and cellular localization of proteins that depend on oxidative environment to reach their native structure. Unfolded proteins can be translocated into the periplasm post-translationally (Sec mechanism) or co-translationally (SPR mechanism), according to their specific leader sequences. SecB is the physiological chaperone involved in stabilizing unfolded proteins bound to Sec translocation machinery, but the activity of other cytoplasmic chaperones like DnaK can be beneficial. Once in the periplasm proteins folding is mediated by the Dsb oxidases/isomerases, by chaperones such as Skp, DegP and FkpA, and by peptidyl-prolyl isomerases such as SurA, PpiA, and PpiB. Double mutant strains, in which the thioredoxin/glutaredoxin reductase (trx $B^{-}$, gor) pathway is silenced, are characterized by the presence of an oxidizing cytoplasm, compatible with the folding of proteins that need disulfide bridges for stabilizing their structure. Cytoplasmic accumulation of correctly folded disulfide-dependent proteins is improved by disulfide isomerase DsbC co-expression and cytoplasmic chaperone (DnaKJE, GroELS, ClpB). Finally, proteins provided with a Tat export leader sequence first fold in the cytoplasm and then are tanslocated into the periplasm. Chaperones like DnaKJE, can stabilize the precursor in the cytoplasm and chaperones such as SlyD and TorD support the pathway efficiency probably binding to the export leader peptide.

ment. In eukaryotic cells, the oxidative environment in which disulfide bonds are preferentially formed is the endoplasmic reticulum (ER). Therefore, polypeptides expressed in the reducing cytoplasm need to be directed to ER to complete their folding. The correct targeting to the subcellular compartment is mediated by signal peptides fused to the protein amino terminus that are removed after the import into the organelle. Prokaryotes share with eukaryotic cells the reducing cytoplasm, but do not have structures resembling the ER. Instead of it, they possess an oxidizing periplasm to which pro-peptides with an extra $\mathrm{N}$-term export peptide can be translocated. Therefore, eukaryotic protein expression in bacteria periplasm is possible following the substitution of the ER with a bacterial signal sequence for periplasm translocation.
Alternative strategies consider promoting the formation of disulfide bonds by targeting the nascent polypeptides to the external medium or by modifying the redox state of cytoplasm to reach a mild oxidative environment (Figure 1 ). Both overexpression and direct fusion to chaperones, foldases, and stabilizing carriers has been tested for improving the yields of functional target proteins.

Finally, protein aggregates can be first dissolved in chaotropic solutions to reach monodispersity and later be used as a starting material for oxidative refolding processes. A flowchart of the different alternatives is reported in Figure 2.

\section{Periplasmic expression}

The most intuitive method to exploit E. coli for recovering folded disulfide-bond dependent recombinant proteins is to direct the translated polypeptides to the bacterial periplasm. There are clear physiological reasons for such an approach: the periplasm, in contrast to the cytoplasm, is an oxidizing compartment and it hosts enzymes catalyzing disulfide bond formation and their isomerization, as well as specific chaperones and foldases [1-3]. However, the necessity of translocating nascent polypeptides through the inner membrane introduces a delicate step since there is only a limited number of available gates for

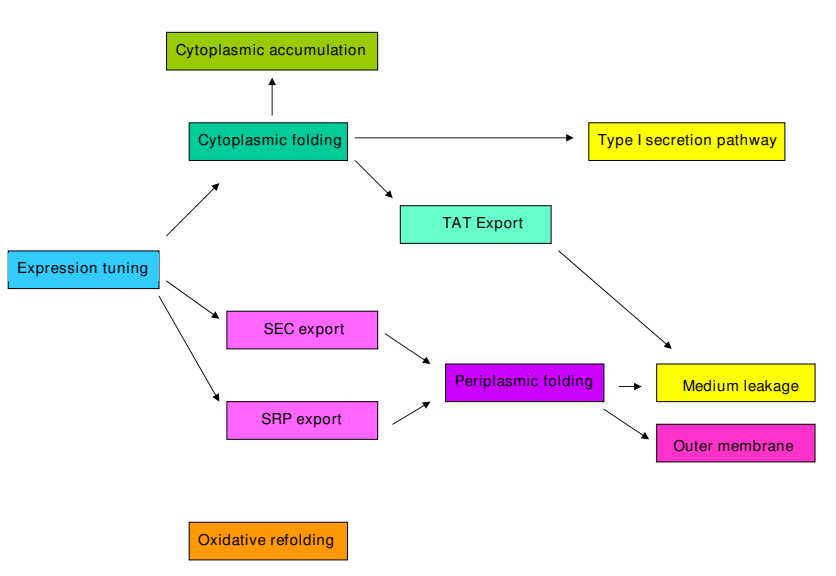

\section{Figure 2}

Flow-chart summarizing the different possibilities for producing disulfide-dependent proteins in bacteria. Expression is optimized and protein folding directed either in the cytoplasm or in the periplasm. Once folded in the cytoplasm, proteins can accumulate in the same cell compartment, or be exported to the periplasm by the Tat-pathway, or be secreted to the medium by the type I secretion system. Unfolded proteins can be translocated post-translationaly (Sec) or co-translationaly (SPR) into the periplasm and accumulate there, leak to the medium, or be exposed on the outer membrane. Precipitated proteins can be recovered into native structure by means of oxidative refolding. 
reaching the periplasm and metastable precursors may consequently accumulate in the cytoplasm.

\section{Modulation of the expression level}

Considering the potential danger of having an overcrowded cytoplasm, some authors proposed that protein secretion could be effectively modulated at the translational level by modifying the Shine-Dalgarno sequence [4]. Other authors found that the crucial tuning region starts upstream of the Shine-Dalgarno region and spans approximately twenty nucleotides downstream of the initiation codon (translational initiation region) [5]. Coherently, also other parameters influencing the expression rate have been evaluated in relationship with the production of disulfide-bond dependent proteins, such as growth medium, plasmid origin of replication, and expression promoters. For instance, the expression features of tac, uspA, uspB, T7, trc, lacUV5, malK, pm/xylS have been investigated to achieve high product yields by preventing protein precipitation and cell lysis [6-12]. However, data have been collected under different experimental conditions and, therefore, they are not comparable, preventing the identification of surely preferable systems.

\section{Choice of the suitable secretion leader peptide}

In the absence of an N-terminal signal peptide for periplasmic secretion, recombinant polypeptides expressed in bacteria accumulate in the cytoplasm. The fusion to suitable leader peptides allows for the translocation of unfolded precursors into the periplasm by either the Sec (relatively slow, post-translational translocation) or the SRP (fast, co-translational translocation) system [13,14], even in the case of aggregation prone proteins such as PNGase and large molecules like full-length immunoglobulins $[15,16]$. The search for optimal leader peptides to use in combination with recombinant proteins has been initially undertaken by comparing the efficiency of natural signal sequences identified in the precursors of bacterial periplasmic proteins, including the leader peptides from $s p A$, phoA, ribose binding protein, pelB, ompA, ompT, $d s b A$, torA, torT, and tolT. Furthermore, both synthetic sequences and the phage pIII leader peptide were used $[6,9,17-22]$. Initially, the approach was not systematic and no clear preference for any among them was apparent, although ompT resulted preferable when coupled to overexpression of chaperones involved in the stabilization of intermediates translocated through the Sec export machinery [23].

However, a wide survey performed by Beckwith and coworkers identified a strong correlation between hydrophobicity of the leader peptide and export mechanism [24]. Apparently, cotranslational translocation by SRP needs the presence of highly hydrophobic leader sequences, even though further unknown biophysical features may be critical. The physiological necessity of the SRP pathway as an alternative to the post-translational secretion meditated by the Sec route is required to avoid premature folding of the proteins in the cytoplasm. The biotechnological implication of these conclusions is that poor periplasmic accumulation of rapidly folding recombinant proteins may be the consequence of their non-productive cytoplasmic (mis)folding that prevents efficient translocation and correct periplasmic folding. Therefore, the choice of the leader peptide may make the difference in terms of secretion efficiency, as demonstrated for thermodynamic stable proteins $[25,26]$.

\section{Mechanism of protein oxidation in the periplasm}

Spontaneous protein oxidation in extracytoplasmic compartments is extremely slow and is incompatible with cell activity. Therefore, it is necessary that the disulfide bond formation is enzymatically catalyzed. Periplasmic protein oxidation is regulated by the five members of the Dsb protein system (DsbA, B, C, D, G) [1,2]. With the exception of DsbB, these proteins belong to the thioredoxin protein superfamily and are involved in both disulfide-bond formation and rearrangement. Specifically, the soluble monomer protein DsbA donates its disulfide bond to newly synthesized polypeptides (Figure 3 ) that are folding intermediates and need disulfide bonds to reach their native structure. Interestingly, DsbA binds its substrates by hydrophobic interactions using a chaperone-like recognition mechanism specific for partially unfolded proteins [27]. Such substrate-independent chaperone-like activity

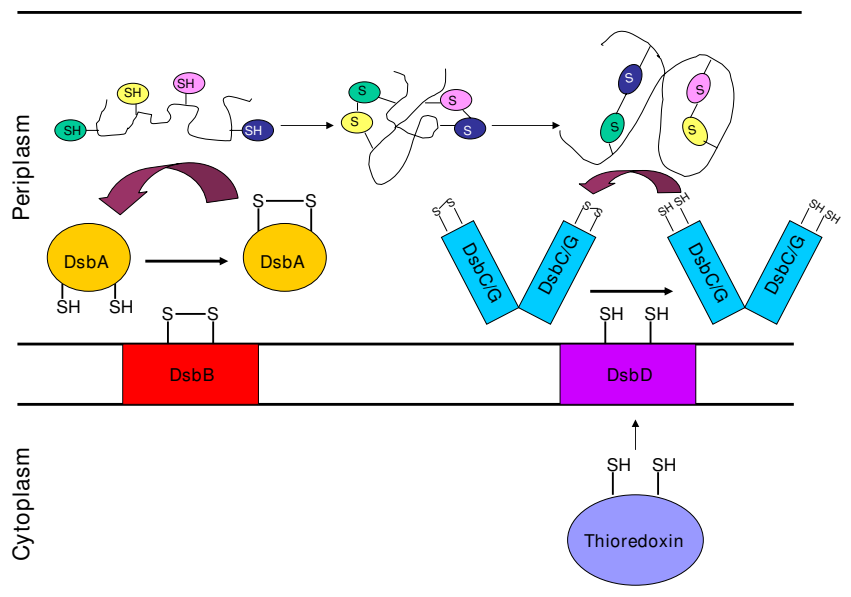

Figure 3

Dsb-dependent protein oxidation and isomerization in the bacterial periplasm. DsbA couples consecutive cysteines providing the disulfide bond and is re-charged by the inner membrane DsbB. Incorrect disulfides of oxidized proteins are scrambled by DsbC and DsbG. These isomerases are kept reduced by the inner membrane DsbD that, in return, is reduced by cytoplasmic thioredoxin. 
seems to have a general stabilizing effect on passenger proteins fused to DsbA mutant deprived of its oxidoreductase activity and, therefore, it has been successfully used as fusion partner even for the production of cytoplasmic proteins [28].

DsbA active site is regenerated by the transfer of electrons to the DsbB integral membrane protein, whose activity is crucial in maintaining DsbA in its active state (Figure 3) [27,29-32]. The DsbA/DsbB mediated oxidative process is very efficient, but may result in incorrect cysteine pairing and in trapping the target protein in non-native conformations. Therefore, a quality control mechanism for the rearrangement of the disulfide bonds was initially postulated and later identified. DsbC and DsbG are the isomerases that scramble incorrect cystin bridges and, therefore, play a key-role in the periplasmic protein folding process (Figure 3) [33-36]. The active cysteines of DsbC and DsbG must remain reduced in an oxidizing environment to be functional. This condition is achieved by the action of the integral inner membrane DsbD. Such protein constantly reduces the isomerases by transferring to them the electrons made available by the cytoplasmic thioredoxin [3741]. Similarly to DsbA, both DsbC and DsbG have chaperone activity. Since misfolding could be a direct consequence of incorrect disulfides, DsbC/DsbG chaperone activity favors the recognition and interaction with substrates necessiting disulfide isomerization [1,42]. Such homodimer isomerases are $\mathrm{V}$-shaped and use the structure flexibility of the cleft embodied by the two arms to bind unfolded structures of various sizes. Their adaptability allows the recognition of largely heterogeneous substrates and explains the elevated efficiency of bacterial DsbC/ DsbG in isomerasing also heterologous proteins [1].

Although the two routes of keeping DsbA oxidized and DsbC/DsbG reduced have been always considered strictly separated [1], recent data indicate a possible direct cooperation between DsbA and DsbC [43], and chimeras of DsbA and DsbC proved to be able to serve both as oxidase and as isomerase, thus reconciling the competing pathways leading to DsbA oxidation and DsbC reduction [44]. Furthermore, it has been demonstrated that DsbA can be mutated to become an isomerase by adding a linker with peptide binding capacity and that provides a dimerisation domain. These characteristics prevent its immediate oxidation by DsbB and allow substrate recognition and binding [45]. Such results will probably simplify the biotechnological applications of Dsb proteins in vitro.

\section{Use of Dsb proteins for biotechnological purposes}

The relevance of the Dsb protein family for the correct folding of disulfide-bond dependent proteins in the E. coli suggested that boosting such molecular machinery could result in increased yields of correctly folded recombinant constructs. The accumulation of a functional $\mathrm{scFv}$ was positively affected by co-expression of DsbA, B, C, D [46], both DsbAB and DsbCD overexpression improved the production of active horseradish peroxidase [47], whilst co-expression of DsbA and DsbC increased the yield of functional human plasma retinol-binding protein [48]. Fusion to DsbA increased the accumulation of few $\mathrm{mg} / \mathrm{L}$ culture medium of active bovine enterokinase and human pro-insulin, a polypeptide stabilized by three disulfide bonds $[49,50]$. However, in the case of Ragi bifunctional inhibitor, a protein with five overlapping disulfide bonds, DsbA activity resulted in the accumulation of non-native intermediates, whilst the availability of DsbC significantly increased the yield of the native protein both in vitro and in vivo [51]. Again, the overexpressoion of DsbA, B, C, D and DsbCD, but not DsbAB, increased the accumulation of active nerve growth factor beta [52] and DsbC was the key foldase also for enhancing the production of horseradish peroxidase and brain-derived neurotrophic factor, although its synergistic effect with DsbA, B, and D was detectable $[53,54]$. These results were confirmed by experiments performed with plasminogen activator and a scFv $[55,56]$ and seem to indicate that the isomerase DsbC activity could be the limiting factor for the correct folding of at least part of the recombinant proteins expressed in the E. coli periplasm.

The different responses observed when using eukaryotic substrates and DsbA or DsbC overexpression might be explained by examining the structure of each single substrate protein. DsbA couples cysteines as soon as they are available and, therefore, only disulfides between consecutive residues are formed. As a consequence, DsbC activity is not necessary for proteins in which only disulfide bonds between consecutive cysteines are present in the native structure [57]. In contrast, bond scrambling is DsbCdependent. The correlation between the presence of nonconsecutive disulfides and DsbC-dependence for achieving the correct folding has been demonstrated for eukaryotic as well as for bacterial proteins $[51,58]$. However, although the bacterial RNaseI is a natural DsbC substrate with three consecutive and one nonconsecutive disulfide bonds [59], it is possible to artificially tune the periplasm redox potential to achieve conditions that allow DsbA to correctly catalyze the bond formation between the nonconsecutive residues [60].

The pivotal role of thiol-disulfide oxidoreductases in supporting the correct folding of disulfide-bond dependent proteins is conserved in Gram-negative bacterial periplasm [61]. Interestingly, functionality seems to be retained also by phylogenetically distant proteins, such as endoplasmic reticulum disulfide isomerase from mammalian and yeast since, despite the low sequence homology, a marked structural similarity exists [62-64]. This 
observation led to successful engineering of human disulfide isomerase in the E. coli periplasm and even in the Gram-positive Bacillus brevis, with consequent functional restoration in $d s b A$ mutants and yield improvement of functional proteins $[65,66]$.

\section{Coexpression of periplasmic chaperones and foldases}

The process leading to correct protein folding in the E. coli periplasm is mediated by the activity of proteins belonging to several classes and that often have partially overlapping functions (Fig 1). There are peptidyl-prolyl isomerases and chaperones such as SurA, FkpA, PpiA, PpiD, and Skp, and chaperone/proteases such as DegP [67-73]. FkpA and SurA overexpression contributed to an increase in the accumulation of functional human plasma retinol-binding protein [48], FkpA, DegP, DsbA, and DsbC rescued the activity of lipase $B[74]$, and both the chaperone and protease activities of DegP were necessary to enhance the yields of penicillin acylase $[71,75]$.

The prolyl-cis/trans isomerase activity of Ppi apparently catalyzes the rate-limiting step of the recombinant antibody folding represented by the isomerization of proline 95 (Kabat numbering) [76]. Its coexpression increased the solubility of scFvs and Fab fragments [77-79], but this enzyme was also successfully used as a fusion partner for recombinant antibody expression $[4,80]$. Similarly, fusions to FkpA resulted in increased yields of functional recombinant antibodies [81,82].

\section{Effect of cytoplasm chaperones on periplasmic protein accumulation}

The mechanisms by which cytoplasmic chaperones can help periplasmic folding are less clear. In a few cases such molecules were directly secreted to the periplasmic space, as was the case of DnaJ and Hsp25 that increased the yields of native plasminogen activator [83]. Probably such molecular chaperones had an unspecific stabilizing effect on folding intermediates, but no sound rationale supports the strategy of boosting the periplasm with cytoplasmic chaperones, instead of using periplasmic ones. In contrast, the idea of overexpressing cytoplasmic chaperones in the cytoplasm might be justified by the consideration that nascent polypeptides are translocated as unfolded intermediates into the periplasm by the Sec/SRP systems and, therefore, their potential aggregation must be prevented (Figure 1). SecB is the natural chaperone that binds polypeptides to be secreted post-translationaly. Apparently, SecB possesses specificity for 9-residue sequence motifs enriched in aromatic and basic residues [84]. The presence of these motifs within recombinant proteins may considerably influence their chances to be correctly delivered to the periplasm by the SEC system. However, the overexpression of other chaperones could compensate for poor SecB binding to non-specific substrates. They might unspecifically recognize and stabilize unfolded polypeptides in the cytoplasm, as suggested by the observation that chaperone overexpression in the cytoplasm was beneficial for the accumulation of some periplasmic proteins [85]. Different combinations have been tested, such as DnaKJE (DnaK, DnaJ, GrpE) that increased the accumulation of functional scFvs against domoic acid and the mycotoxin deoxynivalenol $[56,86]$. DnaKJ co-expression prevented the formation of inclusion bodies of CorA and improved the periplasmic accumulation of granulocyte-colony stimulating factor $[87,88]$. In contrast, cytoplasmic chaperone overexpression failed to improve the yields of horseradish peroxidase [47].

The accumulation rate of $\operatorname{Sec} B$, the physiological chaperone for the Sec system, is apparently efficiently tuned by the effective amount of potential substrates and, consequently, its exogenous overexpression was not considered necessary $[13,89,90]$. However, in at least one case higher periplasmic accumulation of heterologous proteins was detected as a consequence of cytoplasmic SecB overexpression [91]. Other authors found that the overexpression of $\mathrm{SecB}$ and DnaKJ was beneficial in promoting recombinant accumulation of human proteins in the periplasm, but only in combination with signal sequence optimization [92].

\section{Advantages and limitations of fusion constructs}

The problem of stabilizing the folding intermediates has been addressed also by fusing the target polypeptide to protein carriers. Periplasmic EETI-II, erythropoietin, and $\mathrm{scFv}$ production was increased by fusions with maltosebinding protein and immunoglobulin-constant domain, whilst human proinsulin and pepsinogen yields were enhanced by fusions with ecotin, a trypsin inhibitor that could favor target protein accumulation by reducing its degradation [93-96]. A double ecotin-ubiquitin tag has been recently engineered. It should allow both the stabilization of the passenger proteins and their recovery with their authentic amino terminus [12].

It must be underlined that protein fusion always carries an inherent risk of resulting in soluble but incorrectly folded target protein. For instance, fusions of maltose binding protein and some scFvs resulted in higher periplasmic yields, but the antibodies were not functional, whilst the fusion to alkaline phosphatase stabilized both production and activity [97]. Alkaline phosphatase has been often used as a fusion partner for recombinant antibodies. It is not only useful for enhancing the production but, dimerizing, it increases the avidity of the immunoproteins for their substrate and allows their direct detection by enzymatic assay [97-100]. 
Protein A or single and tandem repeats of its B- and Zdomains were successfully used for expressing and purifying a scFv and human proteins such as proinsulin and coagulation factor VII [9,101-105]. Fusion to barnase resulted in correct folding of ICK and McoEeTI, but the construct was directed to the culture medium [106,107].

Other fusion partners, especially in combination with recombinant antibodies, were considered not for facilitating folding and increasing yields, but to obtain reagents more suitable for the final applications. A biotinylationconsensus sequence has been fused to Fab fragments to obtain streptavidin-affine immunoconstructs [108], GFP has been fused to scFvs for recovering immunuofluorescent reagents [109], and fusion to nuclear import/export sequences have been used to direct scFvs to specific subcellular localizations [110].

\section{Effect of chemical chaperones}

A positive effect of low molecular weight additives (chemical chaperones) supplemented in the culture medium was sometimes observed in terms of yields of periplasmic expressed proteins. Sorbitol addition to the culture medium resulted in higher accumulation of a functional scFv [46], glycine betaine and sucrose were beneficial for the folding of immunotoxin and cytochrome c550 $[111,112]$, whilst L-arginine and ethanol increased the yields of human pro-insulin, plasminogen activator, and a scFv $[50,83]$. Also the supply of reduced glutathione, alone or in combination with DsbC overexpression, increased the accumulation of disulfide-dependent proteins $[51,83]$.

\section{Twin-arginine translocase pathway}

Although the Sec and SRP systems are responsible for translocating most of the proteins into the periplasm, bacteria possess another mechanism -the twin-arginine translocase (Tat) pathway- that enables the transport of folded proteins across the inner plasma membrane (Figure 1) [113]. E. coli genome encodes some tens of proteins with a signal-peptide capable of interacting with Tat machinery [114] and such export route has been exploited for recombinant expression as well $[115,116]$. The overexpression of all the tat $A B C$ genes expressing the proteins involved in the transport increased the translocation of a fluorescent reporter [117]. Also the overexpression of the cytoplasmic chaperone DnaK seems particularly useful in increasing the efficiency of the Tat pathway at both physiological and protein overexpression-induced stress conditions $[118,119]$. Such effect could be a consequence of the DnaK role in facilitating the substrate folding into native structures. Another explanation considers that virtually all Tat leader peptides contain recognition sequences for DnaK [120,121]. Therefore, Santini et al. [122] proposed that DnaK sequesters the protein intermediates in the cytoplasm by masking their leader peptide until the folding is complete.

Other chaperone-like proteins as SlyD and TorD have been reported improving Tat efficiency $[118,123,124]$. Interestingly, scFvs correctly folded in the cytoplasm (intrabody mutants or wild type constructs expressed in trx $B^{-}$gor cells) were efficiently transported by the Tat system $[125,126]$.

\section{High throughput selection of suitable clones}

Protein accumulation varies from cell to cell inside a population and, therefore, strategies for selecting the most productive clones are relevant. Similarly, it may be necessary to identify, within large bacteria cultures expressing clone libraries, the few cells producing proteins/antibodies with desired features. Flow cytometry represents a powerful methodology since it enables a quick and thorough screen of large numbers of constructs and it has been successfully applied for selecting proteins, recombinant and full-length antibodies accumulated in the periplasm [127-132]. Several approaches have been described, all referring to the same principle of labeling proteins accumulated in the periplasm to enable the isolation of the productive bacteria. In the simplest protocol, proteins accumulate directly in the the periplasm, otherwise recombinant antibodies are anchored to the periplasmic side of the inner membrane through a lipoprotein domain, or full-length antibodies, secreted and folded in the periplasm, are captured through their Fc domain by an anchoring fusion construct consisting of the Z-domain of the Protein $A$ and an inner membrane lipoprotein $[129,132]$. The outer membrane is successively permeabilized to form spheroplasts and the recombinant proteins/ antibodies are labeled by binding to fluorescent antibodies/antigens. Finally, the cultured bacteria are sorted by flow cytometry according to the expression and affinity of the produced constructs. Such approach may become a paradigm for efficiently screening tagged proteins and antibodies expressed in the periplasmic space.

\section{Periplasmic inclusion body formation}

Despite the periplasmic quality control and the observation that the FkpA chaperone activity seems to be effective in suppressing inclusion body formation [133], proteins can aggregate also in this cellular compartment. The simple overexpression is already sufficient to induce the accumulation of the bacterial beta-lactamase protein inclusion bodies into the periplasm $[134,135]$. Similarly to what was observed in cytoplasmic aggregates, the proteins trapped in periplasmic inclusion bodies may partially preserve their physiological activity [135] and induce stress response [136]. There are relatively few papers reporting the accumulation of heterologous protein inclusion bodies in bacterial periplasm $[8,75,137-139]$. However, the 
number might be underestimated because cell fractionation is rarely undertaken and negative results are often not communicated. From the available information it seems that construct instability is often present in engineered polypeptides. For instance, both the addition of unpaired cysteines and sub-optimal length or composition of the linkers connecting the variable domains may be strongly detrimental for the scFv yields [140,141]. Jeong and Lee systematically tried to alleviate heterologous protein precipitation in the periplasm by analyzing the effect of bacterial strain, growth temperature, expression vector features (signal peptide, promoter, codon usage optimization, linker compositions), and DsbA co-expression, but general conclusions require further studies $[8,142]$.

\section{Induced accumulation of periplasmic proteins into the culture medium}

The recovery of periplasmic proteins is usually achieved by disruption of the outer membrane by osmotic shock. Such purification protocol has the advantage of limiting the contamination with cytoplasmic material. However, as an alternative it has been also proposed to induce the lysis of the outer membrane to recover the target protein directly from the culture medium avoiding a cumbersome purification step (Figure 2). The most investigated solution is based on the expression of Kil protein, a bacteriocin that induces periplasmic protein release through induced membrane solubilization [143,144]. Lysis can be induced by regulating the Kil protein expression with a stationary-phase or a temperature inducible promoter $[145,146]$ and the strategy was successfully used to recover from the medium interleukin-2, beta-glucanase, and streptavidin $[144,145,147]$. Also the co-expression of the TolA protein has been proposed for inducing the external membrane permeabilization [17].

The accumulation of proteins in the culture medium, and specifically of recombinant antibodies, expressed for being secreted into the periplasm has been often observed $[148,149]$. The reasons remain unknown and cell lysis does not seem to be always involved in the protein leakage. However, it has been shown that several different factors such as growth conditions, inducer concentration, and aminoacid substitutions can tune the leakage of scFvs and have been proposed as means to regulate scFv partition between periplasm and medium $[149,150]$. The influence of the expression level on protein leakage from the periplasm to the growth medium has been directly demonstrated comparing different promoters [10].

\section{Cytoplasmic expression}

Early observations indicated that the disulfide bridges in both $\beta$-lactamase and alkaline phosphatase precursors expressed in E. coli were formed only after their translocation and processing in the periplasm and that it was pos- sible to prevent their oxidative folding by trapping the precursors in the cytoplasm $[151,152]$. These results were explained by the presence of a reducing cytoplasm and an oxidizing periplasm in bacteria. Furthermore, they indicated that no protein requiring the formation of disulfide bonds for reaching its native structure can be produced in a functional form in the cytoplasm. The correlation between presence of disulfide bonds and native, functional structures was exploited by Beckwith and co-workers in their pioneering attempt to identify mutations that enabled the formation of active alkaline phosphatase in bacteria cytoplasm. It turned out that alkaline phosphatase folded correctly when expressed in bacteria hosting mutations that blocked the reduction of cysteines in the cytoplasm by silencing the activity of the thioredoxin reductase [153]. The preliminary model indicated that NADPH was the source of reducing potential used by thioredoxin reductase to reduce oxidized thioredoxin. However, the data suggested that another thioredoxin-like protein could be involved in a parallel reducing route. The search for complementary reducing mechanism(s) led to the identification of a second thioredoxin and of glutathione oxidoreductases, all involved in the mechanism aimed at reducing cytoplasmic cysteines [154,155]. The apparent redundancy of the reducing machinery is probably due to the necessity of obtaining the maximal electron transfer efficiency between protein pairs with varying redox potentials [156]. Under physiological conditions the directionality of the electron flux is maintained. However, it was shown that thioredoxin acts as a reductase only when it remains constantly reduced by the thioredoxin reductase activity. In contrast, it can catalyze substrate oxidation when exported to periplasm and oxidized by DsbB $[157,158]$. Also glutaredoxin 3 can catalyze disulfide bond formation in the periplasm, but its activity depends on oxidized glutathione availability rather than DsbB [159]. A similar process has been already demonstrated in eukaryotic cells [160] and its existence may also be hypothesed in the bacterial cytoplasm wherethe environment becomes oxidized as a consequence of impaired reducing activities.

Summarizing, it is possible to obtain an oxidizing cytoplasm in a cellular system in which glutaredoxin activity is abrogated by gor mutation, and both thioredoxin 1 and 2 are kept oxidized as a consequence of thioredoxin reductase mutations (Figure 1). Reduced glutathione, necessary to preserve cell viability, is produced by the disulfide reductase activity of mutated peroxiredoxin AhpC $[161,162]$. Interestingly, AhpC reductase activity does not significantly influence the oxidizing condition of the cytoplasm in $\operatorname{tr} x B^{-}$, gor cells [162]. Such observation prompted to investigate the biotechnological potential of both single $\left(\operatorname{tr} x B^{-}\right)$and double (trx $B^{-}$, gor $)$mutant strains -now commercialized with the names of AD494 and Origami 
(Novagen), respectively- for the cytoplasmic expression of recombinant proteins with multiple disulfide bonds in their native structure. The encouraging data obtained in the first attempts [163] were further improved by combining cytoplasmic oxidation conditions and cytoplasmic accumulation of DsbC isomerase (Figure 1) [164].

Recently, a new expression strain has become available. SHuffle (New England BioLab) is $\operatorname{trxB}^{-}$, gor as the commercial Origami (Novagen), but overexpresses cytoplasmic DsbC and is spectinomycin selectable, allowing the transformation with the majority of the currently used vectors. Although no literature is available so far, it is expected that the SHuffle combination of oxidizing conditions and isomerization capability would strongly improve the correct folding of disulfide bond-dependent proteins in the E. coli cytoplasm.

The method of expressing disulfide-bond-dependent proteins in oxidized cytoplasm was validated by several groups and progressively optimized. The collagen prolyl 4-hydrolases yield was higher in the cytoplasm of $\operatorname{tr} x \mathrm{~B}^{-}$, gor bacteria than in the periplasm of the corresponding BL21 wild type strain [165]. The oxidized cytoplasm allowed the accumulation of functional IgG-like extracellular domain receptor [166], Ig2 domain of neurolin [167], lipase B [168,169], chitinase [170], and anti-freeze proteins [171]. Furthermore, the correct formation of disulfide bonds in the cytoplasmic milieu has been proved in recombinant oxalate oxidase [172], peanut allergen Ara h 2 [173], and Stereum purpureum endopolygalacturonase [174].

\section{A specific class of disulfide-bonded proteins: the recombinant antibodies}

As a consequence of the constantly increasing importance of recombinant antibody expression, a significant effort has been dedicated for optimizing their production in bacteria. Although few antibodies are stable in the absence of disulfide bonds and can be directly expressed as intrabodies in the reducing cytoplasm of host cells [175-179], the structure and the functionality of most of them strictly depends on correct cys-cys bridges.

Recombinant antibodies in scFv format have one intrachain disulfide bond for each variable region, those in Fab format have a further inter chain bond. A scFv fragment fused to a consensus peptide for obtaining in vivo site-specific biotinylation, a bivalent Fv antibody fragment fused to molybdopterin synthase to induce its oligomerization, and some Fab fragments were successfully produced in the cytoplasm of $\operatorname{trxB} \mathrm{B}^{-}$, gor cells [180-182]. Camelidae recombinant antibodies in $\mathrm{VHH}$ format possess one intrachain disulfide bond between framework residues and may have a further one to constrain the CDR3 loop. Also these antibodies and have been successfully produced in the cytoplasm of $\operatorname{tr} x B^{-}$, gor bacteria [183].

\section{Stabilizing role of chaperones and DsbC isomerase}

Chaperones and isomerase can facilitate the target protein folding by impairing non-productive aggregation of folding intermediates and have been often co-expressed. The cytoplasmic overexpression of the periplasmic chaperone Skp and of DsbC isomerase, as well as of the molecular chaperones GroELS and trigger factor, significantly improved the yields of recombinant antibodies [184], whilst the cytoplasmic co-expression of Skp and FkpA were ineffective in rescuing fibrolase venom, in contrast to the beneficial effect of DsbC [185]. The work of other groups confirmed that the cytoplasmic co-expression of DsbC in $\operatorname{trx} B^{-}$, gor -bacteria was advantageous for the functional cytoplasmic accumulation of recombinant antibodies in both scFv and VHH format $[183,186]$. In such conditions the oxidizing environment favors the formation of the cys-cys bridges inside the polypeptide sequence and the isomerase apparently improves the yields of correctly folded antibodies by exchanging the cysteine residues involved in non-native pairing. The strategy of coupling cytoplasm oxidative conditions and isomerase activity was optimized by Yuan et al. [187] who overproduced thioredoxin fusions of calobin venom in the presence of cytoplasmic trapped DsbC. Co-expression of DsbC, GroELS and, at lower extent, of trigger factor resulted in higher yields of a functional $\mathrm{scFv}$ against the receptor c-Met [188], whilst the recombinant co-expression of a peptidyl-prolyl isomerase from Pyrococcus improved yields and functionality of recombinant $\mathrm{Fab}$ fragment [189]. A well-documented review addressing the specific problem of the recombinant antibody expression in prokaryotes has been published by Arbabi-Ghahroudi et al. [190].

\section{Thioredoxin overexpression}

The cytoplasmic accumulation of thioredoxin as a consequence of its recombinant overexpression in wild type bacteria was proposed for increasing the yields of coexpressed eukaryotic proteins without disulfide bonds in their native structure [191]. Similarly, the precipitation of eukaryotic disulfide-bond independent proteins in the bacteria cytoplasm was prevented after their fusion to thioredoxin [192]. Cytoplasmic expression of thioredoxin fusions rescued also polypeptides that failed to correctly fold in the periplasm [187], plant viscotoxins, and porcine pepsinogen $\mathrm{A}$, although these proteins contain multiple disulfide bridges $[193,194]$. The reasons as to why thioredoxin can stabilize its passenger proteins in wild type bacteria is not well understood, although its contribution to scFv folding might be due to its chaperone prop- 
erties [195], since a catalytic cysteine thioredoxin mutant was still effective in supporting both disulfide bond formation and functionality of the target protein [196].

In contrast, there is a logical reason for overexpressing cytoplasmic thioredoxin in double mutant $\operatorname{tr} x B^{-}$, gor-bacteria since such enzyme can act as an oxidant when it operates in an oxidized milieu [157]. Therefore, it can actively contribute to maintain oxidizing conditions in the cytoplasm. Fusions between recombinant scFvs and thioredoxin 1 expressed in $\operatorname{trxB}^{-}$, gor bacteria resulted in increased cytoplasmic yields [196], correct folding of a scFv against the c-Met receptor [188], and of the first domain of the multiple Kazal-type inhibitor LEKTI, a polypeptide that contains two disulfide bridges in its native structure [197]. Both the His- and GST-fusions of BSPH1, a protein containing 2 fibronectin type-II domains each consisting of 2 disulfide bonds, aggregated when expressed in the cytoplasm of $\operatorname{tr} x B^{-}$, gor bacteria, but their fusions with thioredoxin resulted insoluble and active proteins [198].

\section{Carriers used to improve protein correct folding}

Other proteins have been used as fusion partners and showed positive effects on folding and functionality of recombinant proteines accumulated in bacteria cytoplasm. Carboxyterminus fusions to maltose binding protein stabilized several scFvs independently on the cytoplasm redox conditions [199], although less efficiently than thioredoxin [196], whilst fusion to NusA was strictly necessary to yield another functional $\mathrm{scFv}$ and APRIL in the cytoplasm of $\operatorname{tr} x B^{-}$, gor cells [200,201]. Sumo has also been proposed as solubilizing carrier for disulfide-bonded proteins, but the structural quality of the recovered proteins has not been investigated $[202,203]$. However, in a recent report it has been shown that a scFv against VEGF-165 was soluble and active when expressed fused to sumo [204].

\section{Minimal redox conditions compatible with disulfide bond formation}

Although the rational background for the expression of disulfide-bond dependent proteins in double mutant strain $\operatorname{tr} x B^{-}$, gor is generally accepted and such strain has been successfully exploited, alone or in combination with the expression of foldases/chaperones, the usefulness of the single $\operatorname{tr} x B^{-}$mutation remains unclear. The glutathione oxidoreductase is still functional in such bacteria and its activity should be sufficient to keep the cytoplasm partially reduced [156]. Consequently, disulfide bond formation should be at least partially impaired. In practice, only minimal amounts of all expressed scFvs remained soluble and functional in the cytoplasm of $\operatorname{trxB}^{-}$(AD494) cells [109] and the advantage over controls was limited also in the presence of thioredoxin co-expression [205]. A direct comparison between AD494 and tr $x B^{-}$, gor bacteria clearly indicated an advantage in using the double mutant [196]. In contrast, the same cells resulted significantly more efficient than conventional XL-Blue cells in producing an anti-progesterone scFv [206]. However, data concerning the oxidation state of this antibody are not reported. Information concerning folding features or functionality is limited also in other cases in which proteins were successfully produced in the cytoplasm of AD494 cells. However, at least in the case of the scorpion neurotoxin Lqq-V and fibronectin II-2 domain from MMP-2, the proteins were both functional and correctly folded [207,208]. Furthermore, the $t r x B^{-}$strain, in combination with DnaKJ coexpression, allowed the production of biological active human SPARC in the cytoplasm [209]. In the case of a serpin domain, AD494 cells did not improve the total amount of soluble recombinant protein accumulated in the cytoplasm with respect to wild type bacteria, but it was correctly folded and active, whilst the protein expressed in the control cells did not form the essential disulfide bonds [210]. GroELS co-expression further increased the serpin domain solubility. In some cases, the combination of AD494 cells and thioredoxin fusions significantly improved the expression of functional target proteins. Leishmania chitinase, the extracellular domain of human thyrotropin receptor, and the disintegrin domain of jararhagin venom were purified, in large amounts, as soluble and active proteins [211-213].

In contrast, it has been reported that a pro-urokinase fusion with thioredoxin expressed in AD494 (DE3) strain accumulated in inclusion bodies, even when the system was supplemented with disulfide isomerase and chaperonines [214]. However, there is scarce access to negative results that would help in understanding the factors regulating disulfide bond-dependent protein expression in the cytoplasm of wild type and mutant strains.

\section{Protein engineering}

A time-consuming but definitive approach for avoiding trial-and-error attempts in identifying the optimal cytoplasmic expression conditions to yield functional proteins with disulfide bonds is the generation of mutants that maintain a stable structure even in the absence of cys-cys bridges [215]. Such protein engineering efforts were particularly successful in the case of recombinant antibodies. Various strategies of mutation and molecular evolution have been used to generate disulfide-independent stable scFvs starting from a reduction-sensitive precursor [175,216-218]. Intrabodies were recovered from libraries in which CDR variability was introduced by hypermutation of a naturally disulfide bond-independent $\mathrm{VHH}$ or scFv backbone [219,220], and by selecting natural intra- 
bodies by biopanning [186,220-222]. Such molecules are valuable tools with great application potentiality for intracellular immunization $[179,223,224]$.

The substitution of critical residues in both the framework and in the CDRs has also been used to improve the periplasmic accumulation of recombinant antibodies [150,225-227].

\section{Outer membrane-bound proteins}

Expressing secreted proteins anchored on the external side of bacteria membranes [228] has been initially considered to render them accessible for external binders rather than to produce material for purification purpose. Avirulent bacteria displaying peptides corresponding to pathologyrelated antigen determinants on their surface were designed as vaccine tools [229-231]. They succeeded in stimulating immunological reactions [229-234], but the externally anchored peptides were not thoroughly characterized at structural level and, therefore, it cannot be ruled out that immunoresponse was promoted by partially unfolded antigen domains.

However, more recent data show that correctly folded fusions of outer membrane transporters and both $\mathrm{scFv}$ and VHH recombinant antibodies were efficiently translocated on the outer bacteria surface $[235,236]$. Once displayed, anchored proteins can be automatically released into the medium by cleavage of a specific sequence recognized by a membrane protease like OmpT $[233,237]$.

Several bacteria transporter proteins have been used to develop vectors in which they are fused to the proteins of interest $[238,239]$, such as FliC [240], pullulanase [241], OprF [242], OprI [243], PhoE [229], MisL [237,244,245], and cytolysin [234].

Exposing the protein to the outer bacteria surface is a particularly valuable approach when the proteins can be directly used in such format. For instance, enteric coronaviruses were successfully neutralized in cultured epithelial cells treated with $E$. coli expressing fusions of IgA protease beta domain from Neisseria gonnorrhoeae with specific scFvs [246]. An adhesion domain of intimin has been used as an anchoring partner for exposing both proteins and peptide libraries on the surface of the bacteria outer membrane. The resulting bacteria were suitable for cell sorting and used to identify epitope-specific antibodies $[247,248]$.

\section{Type I (extra cellular) secretion pathway}

The type I secretion pathway is used by Gram-negative bacteria to transfer toxins and exoenzymes provided of a carboxyterminus export signal directly from the cytoplasm to the external medium [249-251]. These proteins are devoid of disulfide bridges but the work performed by Fernandez and co-workers demonstrated that fusions of the secreted protein alfa-haemolysin C-domain and antibody fragments devoid of periplasm export signal peptide were efficiently secreted in oxidized and functional form [252-254]. Functional alfa-haemolysin fusions of both scFvs and VHHs were recovered from the culture medium [252-255] and hemolysin-fusion of Shiga toxin B subunit [245] was able to induce host immunoreaction in inoculated rabbits.

\section{Oxidative refolding of denatured proteins}

Despite the great effort made by several groups for obtaining native proteins with correctly folded disulfide bridges in bacteria, many attempts failed and target proteins accumulated as precipitates. This observation prompted other groups to turn the disappointing results into an opportunity of pulling together large amounts of proteins and developing oxidative refolding strategies.

The methodologies available for protein refolding have been thoroughly reviewed [256-258] and here only parameters that are of specific interest for the disulfide bond-dependent proteins will be briefly presented.

Two common requisites for a refolding buffer are the presence of a redox couple and of alkaline $\mathrm{pH}$. The redox couple (GSH/GSSG, MESNA/diMESNA, heteroaromatic thiols) is necessary to activate the cys residues [259-261], whilst the alkaline $\mathrm{pH}$ facilitates the nucleophilic attackdependent disulfide bond formation [262]. Low temperature generally prevents non-productive contacts of metastable folding intermediates and can improve the final yields [263]. Non-productive interactions have been also successfully limited by modifying the reduced thiol groups before starting the refolding process. The cysteines of denatured proteins are first S-sulfonated or transformed into mixed disulfides and then the disulfide bonds are formed in the presence of a suitable redox system $[259,264]$. Surfactants and polyethylene glycol also showed stabilizing properties $[265,266]$, whilst a dynamic redox environment, in which the conditions pass progressively from reductive to oxidative, has been proposed to maximize disulfide bond shuffling [267]. However, also simple dilution was effective for refolding heavy chain single domains [268].

An interesting recent paper shows the contradictory effect that stabilizing molecules may have on the refolding of disulfide-bond dependent proteins [269]. L-arginine is known to slow down the refolding process while suppressing hydrophobic interactions. Both these factors have been usually interpreted as an advantage for efficient refolding. However, although hydrophobic aggregation is prevented, the accumulation of intermediates with free 
cysteines leads to the formation of intermolecular disulfide bonds and the formation of progressively larger oligomers in an arginine-concentration dependent manner.

Productive oxidative refolding can be improved by different means. Chromatography allows separating the target protein from contaminants that can interfere during folding and has been successfully used to achieve the refolding of thioredoxin-scFv fusion proteins [270]. Furthermore, binding unfolded protein to a substrate impairs the physical interaction amongst single molecules and their refolding can be performed in a sort of "independent microenvironment" in which aggregation-driving contacts are prevented. Optimization is necessary with respect to salt concentrations to avoid protein-matrix interactions. Oncolumn refolding was successfully performed by using metal affinity chromatography, as in the case of ribonuclease A [260], chemokines [271], and $\alpha$-glucosidase [272], ion-exchange substrates, as for bovine serum albumin [273] and alfa-lactalbumin [274], or by using zeolite $[275,276]$.

Different classes of proteins can contribute to an increase in the refolding yields of native proteins (Figure 1). Thioredoxin supported the productive refold of both reduced denatured and oxidized but incorrectly paired disulfides of pancreatic RNase, citrate synthase and alphaglucosidase [195,277]. The peptidyl-prolyl isomerase was beneficial for the refolding of Fab fragments [278], whilst the disulfide isomerase, alone or in combination with quiescin-sulphydryl oxidase and glutaredoxin, facilitated the oxidative folding of ribonuclease $\mathrm{A}$ and riboflavin binding protein [279-281]. The fusion to the chaperone SlyD had a positive effect on the refolding of the ectodomain E1 of Rubella virus [282]. DsbA, peptidyl-prolyl-isomerase, and GroEL minichaperone were immobilized on an agarose gel to refold the scorpion toxin Cn5 [283], immobilized DsbA, DsbC and GroEL minichaperone were effective in refolding single-chain fragments [284], disulfide isomerase was beneficial for ribonuclease and lysozyme refolding [285], and DnaK in combination with trigger factor or disulfide isomerase helped the functional folding of $\mathrm{scFv}$ alone and fused to a toxin domain $[286,287]$. The availability of ClpB and DnaK/DnaJ/GrpE improved the refolding efficiency of the cysteine-rich protein gloshedobin [288]. Finally, high-pressure has also been used to prevent the formation of nonnative disulfide bonds [289].

\section{Conclusion}

Often, when very heterogeneous molecules as the proteins are handled, it seems that the only possible approach towards optimization of the production process is the trial-and-error strategy. However, the comprehension of the physiological mechanisms involved in the protein folding and aggregation allowed for more rational solutions that simplified the selection of the conditions to be used in the trial panel (Figure 2).

Robust tools, such as oxidizing mutant strains or plasmids for the overexpression of chaperones and foldases, are now available and several successful expression alternatives have been described. There is still no certainty that a specific disulfide-bond dependent protein will be expressed in a functional form in bacteria, but a series of rational approaches can easily be compared. Once optimized the construct DNA sequence and the expression conditions, the main choice is between cytoplasmic and periplasmic folding and accumulation of the target protein. It will guide the selection of opportune leader sequences and suitable bacteria strains. Finally, the purification strategy will request further modification if the proteins are to be recovered from inclusion bodies, total lysate, periplasmic fractions, or culture medium.

At the end of this review, it becomes apparent that there is a large amount of information missing concerning the accurate description of the molecular mechanisms involved in protein folding, translocation and molecular quality control. There is also a huge gap between the theoretical knowledge and the results of protein production, as these are only sometimes in agreement with the hypothetical expectations and the apparent irrationality of some successful conditions may seem as if it were a "magical" activity. In contrast, what we are missing is a coherent system for the comparison of experimental data that remain anecdotal unless precisely annotated. Our understanding of why some conditions work in one case, but not in another, will substantially increase when a sufficient amount of homogeneous and comparable data will be available for bioinformatic analyses [290]. Data organization and their direct accessibility would help in extrapolating the information necessary to improve the identification of optimal strategies for each specific class of polypeptides. Therefore, the future collective endeavor should be addressed at rationalizing rather than accumulating data. One example to follow for future attempts might be the public repository Refold database http:// refold.med.monash.edu.au/ that lists the successful methods for refolding of proteins [291].

\section{Competing interests}

The author declares that they have no competing interests.

\section{Acknowledgements}

The author wishes to thank Alicja Gruszka for her critical review of the manuscript. 


\section{References}

I. Kadokura H, Katzen F, Beckwith J: Protein disulfide bond formation in prokaryotes. Annu Rev Biochem 2003, 72: I I I-I35.

2. Messens J, Collet J-F: Pathways of disulfide bond formation in Escherichia coli. Int J Biochem Cell Biol 2006, 38: I050-I062.

3. Berndt $\mathrm{C}$, Lillig $\mathrm{CH}$, Holmgren A: Thioredoxins and glutaredoxins as facilitators of protein folding. Biochim Biophys Acta 2008, | 783:64|-650.

4. Mavrangelos C, Thiel M, Adamson PJ, Millard DJ, Nobbs S, Zola H, Nicholson IC: Increased yield and activity of soluble singlechain antibody fragments by combining high-level expression and the Skp peripasmic chaperonin. Protein Expr Purif. 200I, 23(2):289-295.

5. Simmons LC, Yansura DG: Translational level is a critical factor for the secretion of the heterologous proteins in Escherichia coli. Nat Biotechnol 14:629-634.

6. Obukowicz MG, Gustafson ME, Junger KD, Leimgruber RM, Wittwer AJ, Wun TC, Warren TG, Bishop BF, Mathis KJ, McPherson DT, et al.: Secretion of active kringle-2-serine protease in Escherichia coli. Biochemistry 1990, 29:9737-9745.

7. Prytz I, Sanden AM, Nyström T, Farewell A, Wahlström A, Förberg C, Pragai Z, Barer M, Harwood C, Larsson G: Fed-batch production of recombinant beta-galactosidase using the universal stress promoters uspA and uspB in high cell density cultivations. Biotechnol Bioeng 2003, 83:595-603.

8. Jeong KJ, Lee SY: Secretory production of human leptin in Escherichia coli. Biotechnol Bioeng 2000, 67:398-407.

9. Mergulhão FJ, Monteiro GA, Larsson G, Bostrom M, Farewell A, Nyström T, Cabral JM, Taipa MA: Evaluation of inducible promoters on the secretion of a ZZ-proinsulin fusion protein in Escherichia coli. Biotechnol Appl Biochem 2003, 38:87-93.

10. Mergulhão FJ, Monteiro GA, Larsson G, Sanden AM, Farewell A, Nyström T, Cabral JM, Taipa MA: Medium and copy number effects on the secretion of human proinsulin in Escherichia coli using the universal stress promoters uspA and uspB. Appl Microbiol Biotechnol 2003, 6 I:495-50I.

II. Sletta H, Nedal A, Aune TE, Hellebust H, Hakvåg S, Aune R, Ellingsen TE, Valla S, Brautaset T: Broad-host-range plasmid pJB658 can be used for industrial-level production of a secreted hosttoxic single-chain antibody fragment in Escherichia coli. Appl Environ Microbiol 2004, 70:7033-7039.

12. Paal M, Heel T, Schneider R, Auer B: A novel Ecotin-UbiquitinTag (ECUT) for efficient, soluble peptide production in the periplasm of Escherichia coli. Microbial Cell Factories 2009, 8:7.

13. den Blaauwen T, Driessen AJ: Sec-dependent preprotein translocation in bacteria. Arch Microbiol 1996, I65: I-8.

14. Luirink J, Sinning I: SRP-mediated protein targeting: structure and function revisited. Biochim Biophys Acta 2004, I 694:17-35.

15. Loo T, Patchett ML, Norris GE, Lott JS: Using secretion to solve a solubility problem: High-yield expression in Escherichia coli and purification of the bacterial glycoamidase PNGase F. Prot Expr Purif 2002, 24:90-98.

16. Simmons LC, Reilly D, Klimowski L, Raju TS, Meng G, Sims P, Hong $K$, Shields RL, Damico LA, Rancatore P, Yansura DG: Expression of full-length immunoglobulins in Escherichia coli: rapid and efficient production of aglycosylated antibodies. J Immunol Methods 2002, 263:133-147.

17. Wan EW, Baneyx F: TolAIII co-overexpression facilitates the recovery of periplasmic recombinant proteins into the growth medium of Escherichia coli. Protein Expr Purif. 1998, I 4(I): 13-22.

18. Oelschlaeger P, Lange S, Schmitt J, Siemann M, Reuss M, Schmid RD: Identification of factors impeding the production of a singlechain antibody fragment in Escherichia coli by comparing in vivo and in vitro expression. Appl Microbiol Biotechnol 2003, 6I:123-132.

19. Malik A, Rudolph R, Söhling B: A novel fusion protein system for the production of native human pepsinogen in the bacterial periplasm. Protein Expr Purif. 2006, 47(2):662-67I.

20. Sletta H, Tøndervik A, Hakvåg S, Aune TE, Nedal A, Aune R, Evensen $\mathrm{G}$, Valla S, Ellingsen TE, Brautaset T: The presence of $\mathbf{N}$-terminal secretion signal sequences leads to strong stimulation of the total expression levels of three tested medically important proteins during high-density cultivations of Escherichia coli. Appl Environ Microbiol 2007, 73:906-912.
21. Thie H, Schirrmann T, Paschke M, Dübel S, Hust M: SRP and Sec pathway leader peptides for antibody phage display and antibody fragment production in $\boldsymbol{E}$. coli. New Biotechnol 2008, 25:49-54.

22. Schierle CF, Berkmen M, Huber D, Kumamoto C, Boyd D, Beckwith J: The DsbA signal sequence directs efficient, cotranslational export of passenger proteins to the Escherichia coli periplasm via the signal recognition particle pathway. J Bacteriol 2003, | 85:5706-57|3.

23. Ignatova Z, Mahsunah A, Georgieva M, Kasche V: Improvement of post-translational bottlenecks in the production of penicillin amidase in recombinant Escherichia coli strains. Appl Environ Microbiol 2003, 69: I237-I245.

24. Huber D, Boyd D, Xia Y, Olma MH, Gerstein M, Beckwith J: Use of thioredoxin as a reporter to identify a subset of Escherichia coli signal sequences that promote signal recognition particle-dependent translocation. J Bacteriol 2005, I 87:2983-299l.

25. Steiner D, Forrer P, Stumpp MT, Plückthun A: Signal sequences directing cotranslational translocation expand the range of proteins amenable to phage display. Nat Biotechnol. 2005, 24(7):823-831.

26. Steiner D, Forrer P, Plückthun A: Efficient selection of DARPins with sub-nanomolar affinities using SRP phage display. J Mol Biol 2008, 382: I 21 I- I 227.

27. Couprie J, Vinci F, Dugave C, Quemeneur E, Moutiez M: Investigation of the DsbA mechanism through the synthesis and analysis of an irreversible enzyme-ligand complex. Biochemistry 2000, 39:6732-6742.

28. Zhang Y, Olsen DR, Nguyen KB, Olson PS, Rhodes ET, Mascarenhas $D$ : Expression of eukaryotic proteins in soluble form in Escherichia coli. Protein Expr Purif. 1998, I 2(2): I59-165.

29. Bardwell JC, McGovern K, Beckwith J: Identification of a protein required for disulfide bond formation in vivo. Cell I99|, 67:581-589.

30. Bardwell JC, Lee JO, Jander G, Martin N, Belin D, Beckwith J: A pathway for disulfide bond formation in vivo. Proc Natl Acad Sci USA 1993, 90:1038-1042.

31. Missiakas D, Georgopoulos C, Raina S: Identification and characterization of the Escherichia coli gene $d s b B$, whose product is involved in the formation of disulfide bonds in vivo. Proc Natl Acad Sci USA 1993, 90:7084-7042.

32. Jander G, Martin N, Beckwith J: Two cysteines in each periplasmic domain of the membrane protein DsbB are required for its function in protein disulfide bond formation. Embo J 1994 , I 3:5 I 21-5 I 27.

33. Shevchik VE, Condemine G, Robert-Baudouy : Characterization of DsbC, a periplasmic protein of Erwinia chrysantemi and Escherichia coli with disulfide isomerase activity. Embo J 1994 , I 3:2007-2012.

34. Chen J, Song JL, Zhang S, Wang Y, Cui DF, Wang CC: Chaperone activity of DsbC. J Biol Chem 1999, 274:1960I-I9605.

35. Andersen CL, Matthey-Dupraz A, Missiakas D, Raina S: A new Escherichia coli gene, dsbG, encodes a periplasmic protein involved in disulphide bond formation, required for recycling DsbA/DsbB and DsbC redox proteins. Mol Microbiol I997, 26: $121-132$.

36. Bessette PH, Coto JJ, Gilbert HF, Georgiou G: In vivo and in vitro function of the Escherichia coli periplasmic cysteine oxidoreductase DsbG. J Biol Chem 1999, 274:7784-7792.

37. Missiakas D, Schwager F, Raina S: Identification and characterization of a new disulfide isomerase-like protein (DsbD) in Escherichia coli. Embo J 1995, I 4:3415-3424.

38. Stewart EJ, Katzen F, Beckwith J: Six conserved cysteines of the membrane protein DsbD are required for the transfer of electrons from the cytoplasm to the periplasm of Escherichia coli. Embo J 1999, 18:5963-5971.

39. Katzen F, Beckwith J: Transmembrane electron transfer by the membrane protein DsbD occurs via a disulfide bond cascade. Cell 2000, 103:769-779.

40. Rietsch A, Bessette P, Georgiou G, Beckwith : Reduction of the periplasmic disulfide bond isomerase, DsbC, occurs by passage of electrons from cytoplasmic thioredoxin. J Bacteriol 1997, I 79:6602-6608.

4I. Stirnimann CU, Grütter MG, Glockshuber R, Capitani G: nDsbD: a redox interaction hub in the Escherichia coli periplasm. Cell Mol Life Sci 2006, 63:1642-1648. 
42. Shao F, Bader MW, Jakob U, Bardwell JC: DsbG, a protein disulfide isomerase with chaperone activity. J Biol Chem 2000, 275: I3349-13352

43. Vertommen D, Depuydt M, Pan J, leverrier P, Knoops L, Szikora JP, Messens J, Bardwell JC, Collet JF: The disulphide isomerase DsbC cooperates with the oxidase DsbA in a DsbD-independent manner. Mol Microbiol 2008, 67:336-349.

44. Segatori L, Paukstelis PJ, Gilbert HF, Georgiou G: Engineered DsbC chimeras catalyze both protein oxidation and disulfide-bond isomerization in Escherichia coli: reconciling two competing pathways. Proc Natl Acad Sci USA 2004, I 0 I : I00 I8-10023.

45. Arredondo S, Segatori L, Gilbert HF, Georgiou G: De novo design and evolution of artificial disulfide isomerase enzymes analogous to the bacterial DsbC. J Biol Chem 2008, 283:3 |469-3 I 476.

46. Sandee D, Tungpradabkul S, Kurokawa Y, Fukui K, Takagi M: Combination of Dsb co-expression and an addition of sorbitol markedly enhanced soluble expression of single-chain Fv in Escherichia coli. Biotechnol Bioeng 2005, 91 :4I8-424.

47. Kondo A, Kohda J, Endo Y, Shiromizu T, Kurokawa Y, Nishihara K, Yanagi $H$, Yura $T$, Fukuda $H$ : Improvement of productivity of active horseradish peroxidase in Escherichia coli by coexpression of Dsb proteins. J Biosci Bioeng 2000, 90:600-606.

48. Schlapschy M, Grimm S, Skerra A: A system for concomitant overexpression of four periplasmic folding catalists to improve secretory protein production in Escherichia coli. Prot Eng Des Sel 2006, I 9:385-390.

49. Collins-Racie LA, McColgan JM, Grant KL, DiBlasio-Smith EA, McCoy JM, LaVallie ER: Production of recombinant bovine enterokinase catalytic subunit in Escherichia coli using the novel secretory fusion partner DsbA. Biotechnology I 995, I 3:982-987.

50. Winter J, Neubauer P, Glockshuber R, Rudolph R: Increased production of human proinsulin in the periplasmic space of Escherichia coli by fusion to DsbA. J Biotechnol 200I, 84: I 75-I85.

51. Maskos K, Huber-Wunderlich M, Glockshuber R: DsbA and DsbCcatalyzed oxidative folding of proteins with complex disulfide bridge patterns in vitro and in vivo. J Mol Biol 2003, 325:495-5।3.

52. Kurokawa Y, Yanagi H, Yura T: Overproduction of bacterial protein disulfide isomerase (DsbC) and its modulator (DsbD) markedly inhances periplasmic production of human nerve growth factor in Escherichia coli. J Biol Chem 2001, 276: |4393-14399.

53. Kurokawa Y, Yanagi H, Yura T: Overexpression of protein disulfide isomerase DsbC stabilizes multiple-disulfidebonded recombinant protein produced and transported to the periplasm in Escherichia coli. Appl Environ Microbiol 2000, 66:3960-3965.

54. Hoshino K, Eda A, Kurokawa Y, Shimizu N: Production of brainderived neurotrophic in Escherichia coli by co-expression of Dsb proteins. Biosci Biotechnol Biochem 2002, 66:344-350.

55. Qiu J, Swartz JR, Georgiou G: Expression of active human tissuetype plasminogen activator in Escherichia coli. Appl Environ Microbiol 1998, 64:489|-4896.

56. Hu X, O'Hara L, White S, Magner E, Kane M, Wall JG: Optimisation of production of domoic acid-binding scFv antibody fragment in Escherichia coli using molecular chaperones and functional immobilization on a mesoporous silicate support. Protein Expr Purif. 2007, 52(1):194-201.

57. Joly JC, Swartz JR: In vitro and in vivo redox states of the Escherichia coli periplasmic oxidoreductases DsbA and DsbC. Biochemistry 1997, 36:10067-10072.

58. Berkmen $M$, Boyd $D$, Beckwith J: The nonconsecutive disulfide bond of Escherichia coli phytase (AppA) renders it dependent on the protein-disulfide isomerase, DsbC. I Biol Chem 2005, 280: I | 387- I I 394.

59. Hiniker A, Bardwell JC: In vivo substrate specificity of periplasmic disulfide oxidoreductases. J Biol Chem 2004, 279: I2967-I2973.

60. Messens J, Collet JF, Van Belle K, Brosens E, Loris R, Wyns L: The oxidase DsbA folds a protein with a nonconsecutive disulfide. J Biol Chem 2007, 282:3 I302-31307.

6I. Goldstone D, Haebel PW, Katzen F, Bader MW, Bardwell JCA, Beckwith J, Metcalf $P$ : DsbC activation by the $\mathbf{N}$-terminal domain of DsbD. Proc Natl Acad Sci USA 200I, 98:955I-9556.

62. Martin JL: Thioredoxin - a fold for all reasons. Structure 1995, 3:245-250
63. Ferrari DM, Sling H-D: The protein disulphide-isomerase family: unraveling a string of folds. Biochem J 1999, 339: I- I0.

64. Gruber CW, Cemazar M, Heras B, Martin JL, Craik DJ: Protein disulfide isomerase: the structure of oxidative folding. Trends Biochem Sci 2006, 3 I:455-464.

65. Humphreys DP, Weir N, Mountain A, Lund PA: Human protein disulfide isomerase functionally complements a dsbA mutation and enhances the yield of pectate lyase $\mathbf{C}$ in Escherichia coli. J Biol Chem 1995, 270:28210-282I5.

66. Kajino T, Ohto C, Muramatsu M, Obata S, Udaka S, Yamada Y, Takahashi $\mathrm{H}$ : A protein disulfide isomerase gene fusion expression system that increases the extracellular productivity of Bacillus brevis. Appl Environ Microbiol 2000, 66:638-642.

67. Missiakas D, Betton JM, Raina S: New components of protein folding in extracytoplasmic compartments of Escherichia coli SurA, FkpA, and Skp/OmpH. Mol Microbiol. 1996, 2 I (4):87|-884.

68. Dartigalongue C, Raina S: A new heat-shock gene, ppiD, encodes a peptidyl-prolyl isomerase required for folding of outer membrane proteins in Escherichia coli. Embo J 1998, I 7:3968-3980.

69. Schäfer U, Beck K, Müller M: Skp, a molecular chaperone of gram-negative bacteria, is required for the formation of soluble periplasmic intermediates of outer membrane proteins. J Biol Chem 1999, 274:24567-24574.

70. Sklar JG, Wu T, Kahne D, Silhavy TJ: Defining the roles of the periplasmic chaperones SurA, Skp, and DegP in Escherichia coli. Genes Dev 2007, 2 I:2473-2484.

7I. Lin WJ, Huang SW, Chou CP: DegP-coexpression minimizes inclusion-body formation upon overproduction of recombinant penicillin acylase in Escherichia coli. Biotechnol Bioeng 2001, 73:484-492.

72. Miot M, Betton JM: Protein quality control in the bacterial periplasm. Microb Cell Fact. 2004, 3(I):4.

73. Narayanan N, Chou CP: Physiological improvement to enhance Escherichia coli cell-surface display via reducing extracytoplasmic stress. Biotechnol Prog 2008, 24:293-30I.

74. Xu Y, Yasin A, Tang R, Scharer JM, Moo-Young M, Chou CP: Heterologous expression of lipase in Escherichia coli is limited by folding and disulfide bond formation. Appl Microbiol Biotechnol 2008, 8 I (I):79-87. Epub 2008 Aug 29

75. Pan KL, Hsiao HC, Weng CL, Wu MS, Chou CP: Roles of DegP in prevention of protein misfolding in the periplasm upon overexpression of penicillin acylase in Escherichia coli. J Bacteriol 2003, 185:3020-3030.

76. Jäger $M$, Plückthun $A$ : The rate-limiting steps for the folding of an antibody scFv fragment. FEBS Lett I997, 4 I 8: 106-I I0.

77. Bothmann $H$, Plücktuhn A: Selection for a periplasmic factor improving phage display and functional periplasmic expression. Nat Biotechnol 1998, 1 6:376-380.

78. Hayhurst A, Harris WJ: Escherichia coli Skp chaperone coexpression improves solubility and phage display of single-chain antibody fragments. Prot Expr Purif 1999, I 5(3):336-343.

79. Lin B, Renshaw MW, Autote K, Smith LM, Calveley P, Bowdish KS Frederickson S: A step-wise approach significantly enhances protein yield of a rationally-designed agonist antibody fragment in E. coli. Prot Expr Purif 2008, 59:55-63.

80. Hayhurst A, Happe S, Mabry T, Koch Z, Iverson BL, Georgiou G: Isolation and expression of recombinant antibody fragments to the biological warfare pathogen Brucella melitensis. J Immunol Meth 2003, 276: I85-196.

8I. Zhang Z, Song LP, Fang M, Wang F, He D, Zhao R, Liu J, Zhou ZY, Yin $C C$, Lin $Q$, Huang HL: Production of soluble and functional engineered antibodies in Escherichia coli improved by FkpA. Biotechniques 2003, 35:1032-1042.

82. Padiolleau-Lefevre S, Debat H, Phichith D, Thomas D, Friboulet A, Avalle B: Expression of a functional scFv fragment of an antiidiotypic antibody with a beta-lactam hydrolytic activity. Immunol Lett 2006, 103:39-44.

83. Schäffner J, Winter J, Rudolph R, Schwarz E: Cosecretion of chaperones and low-molecular-size medium additives increases the yield of recombinant disulfide-bridged proteins. Appl Environ Microbiol 2001, 67:3994-4000.

84. Knoblauch NT, Rudiger S, Schonfeld HJ, Driessen AJ, Schneider-Mergener J, Bukau B: Substrate specificity of the SecB chaperone. J Biol Cheml I999, 274:34219-34225. 
85. de Marco A, Deuerling E, Mogk A, Tomoyasu T, Bukau B: Chaperone-based procedure to increase yields of soluble recombinant proteins produced in E. coli. BMC Biotechnol 2007, 7:32.

86. Choi GH, Lee DH, Min WK, Cho YJ, Kweon DH, Son DH, Park K, Seo $\mathrm{JH}$ : Cloning, expression, and characterization of singlechain variable fragment antibody against mycotoxin deoxynialenol in recombinant Escherichia coli. Prot Expr Purif 2004, 35:84-92.

87. Chen Y, Song J, Sui SF, Wang DN: DnaK and DnaJ facilitated the folding process and reduced inclusion body formation of magnesium transporter CorA overexpressed in Escherichia coli. Prot Expr Purif 2003, 32:22I-23I.

88. Perez-Perez J, Martinez-Caja C, Barbero JL, Gutierrez J: DnaK/DnaJ supplementation improves the periplasmic production of human granulocyte-colony stimulating factor in Escherichia coli. Biochem Biophys Res Commun 1995, 21 0:524-529.

89. Chou CP, Tseng JH, Kuo BY, Lai KM, Lin MI, Lin HK: Effect of SecB chaperone on production of periplasmic penicillin acylase in Escherichia coli. Biotechnol Prog 1999, 15:439-445.

90. Müller JP: Effects of pre-protein overexpression on SecB synthesis in Escherichia coli. FEMS Microbiol Lett 1999, 176:219-227.

91. Fraipont C, Adam M, Nguyen-Disteche M, Keck W, Van Beeumen J, Ayala JA, Granier B, Hara H, Ghuysen JM: Engineering and overexpression of periplasmic forms of the penicillin-binding protein 3 of Escherichia coli. Biochem J 1994, 298:189-195.

92. Berges $\mathrm{H}$, Joseph-Liauzun $\mathrm{E}$, Fayet $\mathrm{O}$ : Combined effects of the signal sequence and the major chaperone proteins on the export of human cytokines in Escherichia coli. Appl Environ Microbiol 1996, 62:55-60.

93. Hayhurst A: Improved expression characteristics of singlechain $F v$ fragments when fused downstream of the Escherichia coli maltose-binding protein or upstream of a single immunoglobulin-constant domain. Prot Expr Purif 2000, 18:1-10.

94. Christmann A, Walter K, Wentzel A, Krätzner R, Kolmar H: The cysteine knot of a squash-type protease inhibitor as a structural scaffold for Escherichia coli cell surface display of conformationally constrained peptides. Prot Eng 1999, I 2:797-806.

95. Ahaded A, Winchenne JJ, Cartron JP, Lambin P, Lopez C: The extracellular domain of the human erythropoietin receptor: expression as a fusion protein in Escherichia coli, purification, and biological properties. Prep Biochem Biotechnol 1999, 29:163-176.

96. Malik A, Jenzsch M, Lübbert A, Rudolph R, Söhling B: Periplasmic production of native human proinsulin as a fusion to $E$. coli ecotin. Prot Expr Purif 2007, 55(I): I00-III.

97. Martin CD, Rojas G, Mitchell JN, Vincent KJ, Wu J, McCafferty J, Schofield $D$ J: A simple vector system to improve performance and utilization of recombinant antibodies. BMC Biotechnol 2006, 6:46.

98. Suzuki C, Ueda H, Suzuki E, Nagamune T: Construction, bacterial expression, and characterization of hapten-specific singlechain Fv and alkaline phosphatase fusion protein. J Biochem 1 997, I 22:322-329.

99. Griep RA, van Twisk C, Kerschbaumer RJ, Harper K, Torrance L, Himmler G, van der Wolf JM, Schots A: pSKAP/S: An expression vector for the production of single-chain Fv alkaline phosphatase fusion proteins. Prot Expr Purif 1999, 16(I):63-69.

100. Rau D, Kramer K, Hock B: Single-chain Fv antibody-alkaline phosphatase fusion proteins produced by one-step cloning as rapid detection tools for ELISA. I Immunoassay Immunochem 2002, 23: $129-143$.

10I. Kang Y, Yoon JW: Effect of modification of connecting peptide of proinsulin on its export. J Biotechnol 1994, 36:45-54.

102. Nilsson B, Abrahmsen L, Uhlen M: Immobilization and purification of enzymes with staphylococcal protein $A$ gene fusion vectors. Embo J 1985, 4:1075-1080.

103. Hellebust $H$, Bergseth S, Orning L: Expression of the second epidermal growth factor-like domain of human factor VII in Escherichia coli. J Biotechnol 1998, 66(2-3):203-210.

104. Cocca BA, Seal SN, Radic MZ: Tandem affinity tags for the purification of bivalent anti-DNA single-chain Fv expressed in Escherichia coli. Prot Expr Purif 1999, 17:290-298.

105. Mergulhão FJ, Taipa MA, Cabral JM, Monteiro GA: Evaluation of bottlenecks in proinsulin secretion by Escherichia coli. J Biotechnol 2004, 109:3 I-43.
106. Schmoldt HU, Wentzel A, Becker S, Kolmar H: A fusion protein system for the recombinant production of short disulfide bond rich cysteine knot peptides using barnase as a purification handle. Prot Expr Purif 2005, 39:82-89.

107. Niemann HH, Schmoldt HU, Wentzel A, Kolmar H, Heinz DW: Barnase fusion as a tool to determine the crystal structure of the small disulfide-rich protein McoEeTI. J Mol Biol 2006, 356: I-8.

108. Sibler A-P, Kempf E, Glacet A, Orfanoudakis G, Bourel D, Weiss E: In vivo biotinylated recombinant antibodies: high efficiency of labeling and application to the cloning of active anti-human IgG I Fab fragments. J Immunol Methods 1999, 224: I29-I40.

109. Schwalbach G, Sibler A-P, Choulier L, Deryckere F, Weiss E: Production of fluorescent single-chain antibody fragments in Escherichia coli. Prot Expr Purif 2000, 18(2): 121-132.

1 10. Sibler A-P, Nordhammer A, Masson M, Martineau P, Travé G, Weiss $E$ : Nucleocytoplasmic shuttling of antigen in mammalian cells conferred by a soluble versus insoluble single chain antibody fragment equipped with import/export signals. Exp Cell Res 2003, 286:276-287.

III. Barth S, Huhn M, Matthey B, Klimka A, Galinski EA, Engert A: Compatible-solute-supported peroplasmic expression of functional recombinant proteins under stress conditions. Appl Environ Microbiol 2000, 66:1572-1579.

112. Andrews H, Li Z, Altuve-Blanco A, Rivera M, Burnap RL: Expression, mutagenesis, and characterization of recombinant lowpotential cytochrome c550 of photosystem II. Biochemistry 2005, 44:6092-6100.

113. Lee PA, Tullman-Ercek D, Georgiou G: The bacterial twinarginine translocation pathway. Ann Rev Microbiol 2006, 60:373-395

I14. Tullman-Ercek D, DeLisa MP, Kawarasaki Y, Iranpour P, Ribnicky B, Palmer T, Georgiou G: Export pathway selectivity of Escherichia coli twin arginine translocation signal peptide. J Biol Chem 2007, 282:8309-8316.

I15. Thomas JD, Daniel RA, Errington J, Robinson C: Export of active green fluorescent protein to the periplasm by the twinarginine translocase (Tat) pathway in Escherichia coli. Mol Microbiol 200I, 39:47-53.

116. DeLisa MP, Samuelson P, Palmer T, Georgiou G: Genetic analysis of the twin arginine translocator secretion pathway in bacteria. J Biol Chem 2002, 277:29825-2983I.

117. Barrett CM, Ray N, Thomas JD, Robinson C, Bolhuis A: Quantitative export of a reporter protein, GFP, by the twin-arginine translocation pathway in Escherichia coli. Biochem Biophys Res Commun 2003, 304:279-284.

118. Graubner W, Schierhorn A, Brüser T: DnaK plays a pivotal role in Tat targeting of CueO and functions beside SlyD as a general Tat signal binding chaperones. J Biol Chem 2007, 282:7|I6-7|24.

119. Perez-Rodriguez R, Fisher AC, Perlmutter JD, Hicks MG, Chanal A, Santini CL, Wu LF, Palmer T, DeLisa MP: An essential role for the DnaK molecular chaperone in stabilizing over-expressed substrate proteins of the bacterial twin-arginine translocation pathway. J Mol Biol 2007, 367:7 I5-730.

120. Oresnik IJ, Ladner CL, Turner RJ: Identification of a twin-arginine leader binding protein. Mol Microbiol 200I, 40:323-33I.

121. Fisher AC, DeLisa MP: A little help from my friends: quality control of presecretory proteins in bacteria. J Bacteriol 2004, I 86:7467-7473.

122. Santini CL, Ize B, Chanal A, Muller M, Giordano G, Wu LF: A novel sec-independent periplasmic protein translocation pathway in Escherichia coli. EMBO J 1998, 17:101-I I2.

123. Li SY, Chang BY, Lin SC: Coexpression of TorD enhances the transport of GFP via the TAT pathway. J Biotechnol 2006, 122:4|2-42|.

124. Han KY, Song JA, Ahn KY, Park JS, Seo HS, Lee J: Solubilization of aggregation-prone heterologous proteins by covalent fusion of stress-responsive Escherichia coli protein, SlyD. Prot Eng Des Sel 2007, 20:543-549.

125. Ribnicky B, Van Blarcom T, Georgiou G: A scFv antibody mutant isolated in a genetic screen for improved export via the twin arginine transporter pathway exhibits faster folding. J Mol Biol 2007, 369:63I-639.

126. Fisher AC, DeLisa MP: Efficient isolation of soluble intracellular single-chain antibodies using the twin-arginine translocation machinery. J Mol Biol 2009, 385:299-3II. 
127. Georgiou G, Stathopoulos C, Daugherty PS, Nayak AR, Iverson BL, Curtis R III: Display of heterologous proteins on the surface of microorganisms: from the screening of combinatorial libraries to live recombinant vaccines. Nat Biotech I997, I 5:29-34.

128. Chen G, Hayhurst A, Thomas JG, Harvey BR, Iverson BL, Georgiou $\mathrm{G}$ : Isolation of high-affinity ligand-binding proteins by periplasmic expression with cytometric screening (PECS). Nat Biotechnol 2001, 19:537-542.

129. Harvey BR, Georgiou G, Hayhurst A, Jeong KJ, Iverson BL, Rogers GK: Anchored periplasmic expression, a versatile technology for the isolation of high-affinity antibodies from Escherichia coli-expressed libraries. Proc Natl Acad Sci USA 2004, 101:9193-9198.

130. Harvey BR, Shanafelt AB, Baburina I, Hui R, Vitone S, Iverson BL, Georgiou G: Engineering of recombinant antibody fragments methamphetamine by anchored periplasmic expression. J Immunol Methods. 2006, 308( I-2):43-52.

I3I. Jung ST, Jeong KJ, Iverson BL, Georgiou G: Binding and enrichment of Escherichia coli speroplasts expressing inner membrane tethered ScFv antibodies on surface immobilized antigens. Biotechnol Bioeng 2007, 98:39-47.

132. Mazor Y, Van Blarcom T, Mabry R, Iverson BL, Georgiou G: Isolation of engineered, full-length antibodies from libraries expressed in Escherichia coli. Nat Biotechnol 2007, 25:563-565.

133. Arie JP, Sassoon N, Betton JM: Chaperone function of FkpA, a heat shock prolyl isomerase, in the periplasm of Escherichia coli. Mol Microbiol 2001, 39:199-210.

134. Georgiou G, Telford JN, Shuler ML, Wilson DB: Localization of inclusion bodies in Escherichia coli overproducing beta-lactamase or alkaline phosphatase. Appl Environ Microbiol 1986, 52:1157-I|6|.

135. Arie JP, Miot M, Sassoon N, Betton JM: Formation of active inclusion bodies in the periplasm of Escherichia coli. Mol Microbiol 2006, 62:427-437.

136. Hunke S, Betton JM: Temperature effect on inclusion body formation and stress response in the periplasm of Escherichia coli. Mol Microbiol 2003, 50:1579-1589.

137. Liew OW, Choo AB, Too HP: Parameters influencing the expression of mature glial-cell-line-derived neurotrophic factor in Escherichia coli. Biotechnol Appl Biochem 1997, 25:223-233.

138. Casalvilla R, Dueòas M, Ayala M, Cruz S, Cruz L, Buurman WA, Gavilondo JV: A bacterial single-chain Fv antibody fragment that inhibits binding of its parental anti-E-selectin monoclonal antibody to activated human endothelial cells. J Biotechnol 1999, 72:1-12.

139. Lin YH, Fang WL, Lin WJ, Huang SW, Chou CP: Improving production of penicillin acylase in Escherichia coli via efficient DegP. mediated processing of precursors in periplasm. Process Biochem 200I, 37:23-30.

140. Robinson CR, Sauer RT: Optimizing the stability of single-chain proteins by linker length and composition mutagenesis. Proc Natl Acad Sci USA 1998, 95:5929-5934.

141. Schmied A, Breitling F, Winter CH, Queitsch I, Dübel S: Effects of unpaired cysteines on yield, solubility, and activity of different recombinant antibody constructs expressed in $E$. coli. J Immunol Meth 2000, 242(1-2): I01-II4.

142. Jeong KJ, Lee SY: Secretory production of human colony-stimulating factor in Escherichia coli. Prot Expr Purif 200I, 32(2):3||-3|8.

143. Nissen-Meyer J, Rogne P, Oppergård C, Haugen HS, Kristiansen PE: Structure-function relationships of the non-lanthionine-containing peptide (classII) bacteriocins produced by gram-positive bacteria. Curr Pharm Biotechnol 2009, 10:19-37.

144. Miksch G, Ryu S, Risse JM, Flaschel E: Factors that influence the extracellular expression of streptavidin in Escerichia coli using a bacteriocin release protein. Appl Microbiol Biotechnol 2008, $81: 319-326$

145. Beshay U, Miksch G, Friehs K, Flaschel E: Increasing the secretion ability of the kil gene for recombinant proteins in Escherichia coli by using a strong stationary-phase promoter. Biotechnol Lett 2007, 29:1893-1901.

146. Steidler L, Fiers W, Remaut E: Efficient specific release of periplasmic proteins from Escherichia coli using temperature induction of cloned kil gene of pMB9. Biotechnol Bioeng 1994, 44:1074-1082
147. Robbens J, Raeymaekers A, Steidler L, Fiers W, Remaut E: Production of soluble and active recombinant murine interleukin-2 in Escherichia coli: high level expression, Kil-induced release, and purification. Prot Expr Purif 1995, 6(4):48। -486.

148. Stollar BD: Bacterial expression of anti-DNA antibody domains. Methods 1997, I I:12-19.

149. Kipryanov SM, Moldenhauer G, Little M: High level production of soluble single chain antibodies in small-scale Escherichia coli cultures. J Immunol Methods 1997, 200:69-77.

150. Forsberg G, Forsgren M, Jaki M, Norin M, Sterky C, Enhörning $\AA$, Larsson K, Ericsson M, Björk P: Identification of framework residues in a secreted recombinant antibody fragment that control production level and localization in Escherichia coli. J Biol Chem 1997, 272: I 2430-12436.

I5I. Pollitt S, Zalkin H: Role of primary structure and disulfide bind formation in $\beta$-lactamase secretion. J Bacteriol 1983, I 53:27-32.

152. Derman Al, Beckwith J: Escherichia coli alkaline phosphatase fails to acquire disulfide bonds when retained in the cytoplasm. J Bacteriol I99I, I 73:7719-7722.

153. Derman Al, Prinz WA, Belin D, Beckwith J: Mutations that allow disulfide bond formation in the cytoplasm of Escherichia coli. Science 1993, 262:1744-1747.

154. Prinz WA, Åslund F, Holmgren A, Beckwith J: The role of the thioredoxin and glutaredoxin pathways in reducing protein disulfide bonds in the Escherichia coli cytoplasm. J Biol Chem 1997, 272(25): | 566 |- | 5667.

155. Stewart EJ, Åslund F, Beckwith J: Disufide bond formation in the Escherichia coli cytoplasm: an in vivo role reversal for the thioredoxins. EMBO j 1998, 1 7:5543-5550.

156. Åslund F, Beckwith J: The thioredoxin superfamily: redundancy, specificity, and gray-area genomics. J Bacteriol 1999 , | 8 | : | 375- | 379

I57. Debarbieux L, Beckwith J: The reductive enzyme thioredoxin I acts as an oxidant when it is exported to the Escherichia coli periplasm. Proc Natl Acad Sci USA 1998, 95: I075 I-10756.

I58. Jonda S, Huber-Wunderlich M, Glockshuber R, Mossner E: Complementation of DsbA deficiency with secreted thioredoxin variants reveals the crucial role of an efficient dithiol oxidant for catalyzed protein folding in the bacterial periplasm. EMBO J 1999, | 8:327|-328|.

159. Eser M, Masip L, Kadokura H, Georgiou G, Beckwith J: Disulfide bond formation by exported glutaredoxin indicates glutathione's presence in the $E$. coli periplasm. Proc Natl Acad Sci U S A. 2009, I06(5): I572-1577.

160. Ostergaard H, Tachibana C, Winther JR: Monitoring disulfide bond formation in the eukaryotic cytosol. J Cell Biol 2004, 1 66:337-345.

16I. Yamamoto Y, Ritz D, Planson AG, Jnsson TJ, Faulkner MJ, Boyd D, Beckwith J, Poole LB: Mutant AhpC peroxiredoxins suppress thiol-disulfide redox deficiencies and acquire deglutathionylating activity. Mol Cell 2008, 29:36-45.

162. Faulkner MJ, Veeravalli K, Gon S, Georgiou G, Beckwith J: Functional plasticity of a peroxidase allows evolution of diverse disulfide-reducing pathways. Proc Natl Acad Sci USA 2008, I 05:6735-6740.

163. Proba K, Ge L, Plückthun A: Functional antibody single-chain fragments from the cytoplasm of Escherichia coli: influence of thioredoxin reductase (TrxB). Gene 1995, 159:203-207.

164. Bessette PH, Åslund F, Beckwith J, Georgiou G: Efficient folding of proteins with multiple disulfide bonds in the Escherichia coli cytoplasm. Proc Natl Acad Sci USA 1999, 96:13703-13708.

165. Neubauer A, Neubauer P, Myllyharju J: High-level production of human collagen prolyl 4-hydroxylase in Escherichia coli. Matrix Biol 2005, 24:59-68.

166. Kumano-Kuramochi M, Xie Q, Sakakibara Y, Niimi S, Sekizawa K Komba S, Machida S: Expression and characterization of recombinant C-terminal biotynilated extracellular domain of human receptor for the advanced glycation end products (hsRAGE) in Escherichia coli. J Biochem 2008, 143:229-236.

167. Drees C, Stürmer CA, Möller HM, Fritz G: Expression and purification of neurolin immunoglobulin domain 2 from Carrassius auratus (goldfish) in Escherichia coli. Protein Expr Purif. 2008, 59(I):47-54.

168. $\mathrm{Xu} \mathrm{Y,} \mathrm{Lewis} \mathrm{D,} \mathrm{Chou} \mathrm{CP:} \mathrm{Effect} \mathrm{of} \mathrm{folding} \mathrm{factors} \mathrm{in} \mathrm{rescuing}$ unstable heterologous lipase $B$ to enhance its overexpres- 
sion in the periplasm of Escherichia coli. Appl Microbiol Biotechnol 2008, 79:1035-44.

169. Larsen MW, Bornscheuer UT, Hult K: Expression of Candida antartica lipase B in Pichia pastoris and various Escherichia coli systems. Prot Expr Purif 2008, 62:90-97.

170. Kaomek M, Mizuno K, Fujimura T, Sriyotha P, Cairns JR: Cloning, expression, and characterization of an antifungal chitinase from Leucacaena leucocephala de Wit. Biosci Biotechnol Biochem 2003, 67:667-676

171. Bar M, Bar-Ziv R, Scherf T, Fass D: Efficient production of a folded and functional, highly disulfide-bonded-helix antifreeze protein in bacteria. Prot Expr Purif 2006, 48:243-252.

172. Cassland P, Larsson S, Nilvebrant NO, Jönsson LJ: Heterologous expression of barley and wheat oxalate oxidase in an $E$. coli trxB gor double mutant. J Biotechnol 2004, 109:53-62.

173. Lehmann, Hoffmann S, Neudecker P, Suhr M, Becker WM, Rösch P: High-yield expression in Escherichia coli, purification, and characterization of properly folded major peanut allergen Ara h 2. Prot Expr Purif 2003, 31:250-259.

174. Shimuzu T, Shibata H, Araya T, Nakatsu T, Miyairi K, Okuno T, Kato $\mathrm{H}$ : Expression, purification, and crystallization of endopolygalacturonidase from a pathogenic fungus, Stereum purpureum, in Escherichia coli. Prot Expr Purif 2005, 44: I30-I35.

175. Martineau P, Jones P, Winter G: Expression of an antibody fragment at high levels in the bacterial cytoplasm. J Mol Biol 1998 280: II 7-I27.

176. Duan L, Zhu M, Bagasra O, Pomerantz RJ: Intracellular immunization against HIV-I infection of human T lymphocytes: utility of anti-Rev single-chain variable fragment. J Biol Chem 1995, 6:1561-1573.

177. Hassanzadeh Ghassabeh G, Devoogdt N, Ghysen A, De Baetselier P, Muyldermans S, Dambly-Chaudiere C: The regulated expression of an intrabody produces a mutant phenotype in Drosophila. FEBS Lett 1998, 437:81-86.

178. Nizak C, Monier S, del Nery E, Moutel S, Goud B, Perez F: Recombinant antibodies to the small GTPase Rab6 as conformation sensors. Science 2003, 300:984-987.

179. Tanaka T, Williams RL, Rabbitts TH: Tumor prevention by a single antibody domain targeting the interaction of signal transduction proteins with RAS. EMBO / 2007, 26:3250-3259.

180. Santala V, Lamminämki U: Production of biotinylated singlechain fragment in the cytoplasm of Escherichia coli. J Immunol Meth 2004, 284: 165-175.

181. Petrov K, Dion M, Hoffmann L, Dintinger T, Defontaine A, Tellier C: Bivalent Fv antibody fragments obtained by substituting the constant domains of a Fab fragment with heterotetrameric molybdopterin synthase. J Mol Biol 2004, 34 I: 1039-1048.

182. Venturi M, Seifert C, Hunte C: High level production of functional antibody Fab fragments in an oxidizing bacterial cytoplasm. J Mol Biol 2002, 3 i 5: I-8.

183. Olichon A, Surrey T: Selection of genetically encoded fluorescent single-domain antibodies engineered for efficient expression in Escherichia coli. J Biol Chem 2007, 282:363|4-36320

184. Levy R, Weiss R, Chen G, Iverson BL, Georgiou G: Production of correctly folded Fab antibody fragment in the cytoplasm of Escherichia coli trxB gor mutants via the coexpression of molecular chaperones. Protein Expr Purif. 200I, 23(2):338-347.

185. Zhang ST, Shi J, Zhao J, Qi YF, Guo AG: Expression of soluble and functional snake venom fibrinolytic enzyme fibrolase via the co-expression of DsbC in Escherichia coli. Prot Pept Lett 2006, 13:559-563.

186. Jurado P, Ritz D, Beckwith J, de Lorenzo V, Fernandez LA: Production of functional single-chain Fv antibodies in the cytoplasm of Escherichia coli. J Mol Biol 2002, 320: I- I0.

187. Yuan S, Duan H, Liu C, Liu X, Liu T, Tao H, Zhang Z: The role of thioredoxin and disulfide isomerase in the expression of the snake venom thrombin-like enzyme calobin in Escherichia coli BL2I (DE3). Prot Expr Purif 2004, 38(I):5I-60.

188. Heo M-A, Kim S-H, Kim S-Y, Kim Y-J, Chung J, Oh M-K, Lee S-G. Functional expression of single-chain variable fragment antibody against c-Met in the cytoplasm of Escherichia coli. Prot Expr Purif 2006, 47:203-209.

189. Ideno A, Furutani M, Iba $Y$, Kurosawa $Y$, Maruyama T: FK506 binding protein from the hyperthermophilic archaeon Pyrococcus horikoshii suppresses the aggregation of proteins in Escherichia coli. Appl Environ Microbiol 2002, 68:464-469.

190. Arbabi-Ghahroudi M, Tanha J, MacKenzie R: Prokaryotic expression of antibodies. Cancer Metastasis Rev 2005, 24:50I-5I9.

191. Yasukawa T, Kanei-Ishii C, Maekawa T, Fujimoto J, Yamamoto T, Ishii $\mathrm{S}$ : Increase of solubility of foreign proteins in Escherichia coli by coproduction of the bacterial thioredoxin. J Biol Chem 1995 , 270:25328-25331.

192. LaVallie ER, DiBlasio EA, Kovacic S, Grant KL, Schendel PF, McCoy $J M$ : A thioredoxin gene fusion expression system that circumvents inclusion body formation in the E. coli cytoplasm. Biotechnology 1993, II:187-193.

193. Tanaka T, Yada RY: Expression of soluble cloned porcine pepsinogen A in Escherichia coli. Biochem J 1996, 3 I 5:443-446.

194. Bogomolovas J, Simon B, Sattler M, Stier G: Screening of fusion partners for high yield expression and purification of bioactive viscotoxins. Protein Expr Purif. 2008, 64(I):16-23. Epub 2008 Oct 17

195. Kern R, Malki A, Holmgren A, Richarme G: Chaperone properties of Escherichia coli thioredoxin and thioredoxin reductase. Biochem J 37 I:965-972.

196. Jurado P, de Lorenzo V, Fernandez LA: Thioredoxin fusions increase folding of single chain Fv antibodies in the cytoplasm of Escherichia coli: evidence that chaperone activity is the prime effect of thioredoxin. J Mol Biol 2006, 357:49-6I.

197. Lauber T, Marx UC, Schulz A, Kreutzmann P, Rösch P, Hoffmann S: Accurate disulfide formation in Escherichia coli: overexpression and characterization of the first domain (HF6478) of the multiple Kazal-type inhibitor LEKTI. Prot Expr Purif 200I, 22:108-1 I2.

198. Levebvre J, Boileau G, Manjunath P: Recombinant expression and affinity purification of a novel epididymal human spermbinding protein, BSPHI. Mol Hum Reprod 2008, I5:I05-I4.

199. Bach H, Mazor Y, Shaky S, Shoham-Lev, Berdichevsky Y, Gutnick DL, Benhar I: Escherichia coli maltose-binding protein as a molecular chaperone for recombinant intracellular cytoplasmic single-chain antibodies. J Mol Biol 200 I, 3 | 2:79-93.

200. Zheng L, Baumann U, Reymond J-L: Production of a functional catalytic antibody scFv-NusA fusion protein in bacterial cytoplasm. J Biochem 2003, I33:577-58I.

201. Wang SL, Cai YF, Lin QP, Sheng XL, Shui Y, Zhang SQ: Molecular cloning in vitro expression and bioactivity of dog A proliferation-inducing ligand (APRIL). Vet Immunol Immunopathol 2008, 1 28:407-12.

202. Zuo X, Mattern MR, Tan R, Li S, Hall J, Sterner DE, Shoo J, Tran $H$ Lim P, Sarafianos SG, Kazi L, Navas-Martin S, Weiss SR, Butt TR: Expression and purification of SARS coronavirus proteins using SUMO-fusions. Prot Expr Purif 2005, 42:100-110.

203. Assadi-Porter FM, Patry S, Markley JL: Efficient and rapid protein expression and purification of small high disulfide containing sweet protein brazzein in E. coli. Prot Expr Purif 2008, 58:263-268.

204. Ye T, Lin Z, Lei H: High-level expression and characterization of an anti-VEGF 165 single-chain variable fragment (scFv) by small ubiquitin-related modifier fusion in Escherichia coli. Appl Microbiol Biotechnol 2008, 81:3II-3 I7.

205. Kim S, Cheung LH, Zhang W, Rosenblum MG: Improved expression of a soluble single chain antibody fusion protein containing tumor necrosis factor in Escherichia coli. Appl Microbil Biotechnol 2007, 77:99-106.

206. He M, Hamon M, Liu H, Kang A, Taussig MJ: Functional expression of a single-chain anti-progesterone antibody fragment in the cytoplasm of a mutant Escherichia coli. Nucl Acids Res 1995, 23:4009-40I0.

207. Banerjee S, Curto EV, Beckman M, Brown GB, Zhong J, Krishna NR: Expression of functional scorpion neurotoxin Lqq-V in $E$. coli. Peptides 2006, 27:49-54.

208. Peisley AA, Gooley PR: High-level expression of a soluble and functional fibronectin type II domain from MMP-2 in the Escherichia coli cytoplasm for solution NMR studies. Protein Expr Purif. 2007, 53(I):|24-|3|.

209. Schneider EL, Thomas JG, Basuk JA, Sage EH, Baneyx F: Manipulating the aggregation and oxidation of human SPARC in the cytoplasm of Escherichia coli. Nat Biotechnol 1997, 15:581-585. 
210. Lamark T, Ingebrigtsen M, Bjørnstad C, Melkko T, Mollnes TE, Nielsen EW: Expression of active human $\mathrm{Cl}$ inhibitor serpin domain in Escherichia coli. Protein Expr Purif. 2001, 22(2):349-358.

21I. Razek-Desouky A, Specht CA, Soong L, Vinetz JM: Leishmania donovani: expression and characterization of Escherichia coliexpressed recombinant chitinase LdCHTI. Exp Parasitol 200 I, 99:220-225

212. Bobovnikova Y, Graves PN, Vlase H, Davies TF: Characterization of soluble, disulfide-bond stabilized, prokaryotically expressed human thyrotropin receptor ectodomain. Endocrinology 1997, 138:588-593.

213. Moura-da-Silva AM, Linica A, Della-Casa MS, Kamiguti AS, Ho PL, Crampton JM, Theakston RD: Jararhagin ECD-containing disintegrin domain: expression in Escherichia coli and inhibition of the platelet-collagen interaction. Arch Biochem Biophys 1999, 369:295-30I.

214. Sun AL, Hua ZC, Yao J, Yang YH, Yin DQ: Fusion expression of human pro-urokinase with $\mathrm{E}$. coli thioredoxin. Biochem $\mathrm{Mol} \mathrm{Biol}$ Int 1998, 46:479-486.

215. Sanders RW, Hsu ST, van Anken E, Liscaljet IM, Dankers M, Bontjer I, Land A, Braakman I, Bonvin AM, Berkout B: Evolution rescues folding of human immunodeficiency virus-I envelope glycoprotein GP I 20 lacking a conserved disulfide bond. Mol Biol Cell 2008, 19:4707-4716.

216. Proba K, Wörn A, Honegger A, Plückthun A: Antibody scFv fragments without disulfide bonds made by molecular evolution. J Mol Biol 1998, 275:245-253.

217. Martineau P, Betton JM: In vitro folding and thermodynamic stability of an antibody fragment selected in vivo for high expression levels in Escherichia coli cytoplasm. J Mol Biol 1999, 292:921-929.

218. Desiderio A, Franconi R, Lopez M, Villani ME, Viti F, Chiaraluce R, Consalvi $V$, Neri D, Benvenuto $E$ : A semi-synthetic repertoire of intrinsically stable antibody fragments derived from a singleframework scaffold. J Mol Biol 200I, 3 I 0:603-6I5.

219. Saerens D, Pellis M, Loris R, Pardon E, Dumoulin M, Matagne A, Wyns $\mathrm{L}$, Muyldermans $\mathrm{S}$, Conrath $\mathrm{K}$ : Identification of a universal VHH framework to graft non-canonical antigen-binding loops of camel single domain antibodies. I Mol Biol 2005, 352:597-607.

220. Philibert P, Stoessel A, Wang W, Sibler A-P, Bec N, Larroque C, Saven JG, Courtete J, Weiss E, Martineau P: A focused antibody library for selecting scFvs expressed at high levels in the cytoplasm. BMC Biotechnol 2007, 7:8I.

221. Jobling SA, Jarman C, Teh MM, Hlmberg N, Blake C, Verhoeyen ME: Immunomodulation of enzyme function in plants by singledomain antibody fragments. Nat Biotechnol 2003, 2 I:77-80.

222. Rothbauer U, Zolghadr K, Tillib S, Nowak D, Schermelleh L, Gahl A, Backmann N, Conrath K, Muyldermans S, Cardoso MC, Leonhardt H: Targeting and tracing antigens in live cells with fluorescent nanobodies. Nat Methods 2006, 3:887-889.

223. Biocca S, Pierandrei-Amaldi P, Campioni N, Cattaneo A: Intracellular immunization with cytosolic recombinant antibodies. Biotechnology 1994, I 2:396-399.

224. Marasco WA: Intrabodies: turning the humoral immune system outside in for intracellular immunization. Gene 1996, 4(I): II-I5.

225. Knappik A, Plckthun A: Engineered turns of a recombinant antibody improve its in vivo folding. Protein Eng 1995, 8:81-89.

226. Ulrich HD, Patten PA, Yang PL, Romesberg FE, Schultz PG: Expression studies of catalytic antibodies. Proc Natl Acad Sci USA 1995 , 92:11907-11911.

227. Honegger A: Engineering antibodies for stability and efficient folding. Handb Exp Pharmacol 2008, 181 :47-68.

228. Wernerus $H$, Ståhl S: Biotechnological applications for surfaceengineered bacteria. Biotechnol Appl Biochem 2004, 40:209-228.

229. Agterberg M, Adriaanse H, Barteling S, van Maanen K, Tommassen J: Protection of guinea-pigs against foot-and-mouth disease virus by immunization with PhoE-FMDV hybrid protein. Vaccine 1990, 8:438-440.

230. Schorr J, Knapp B, Hundt E, Kupper HA, Amman E: Surface expression of maliaria antigens in Salmonella typhimurium: induction of serum antibody response upon oral vaccination of mice. Vaccine |99|, 9:675-68I.

23I. Dunne M, Al-Ramadi BK, Barthold SW, Flavel RA, Fikrig E: Oral vaccination with attenuated Salmonella typhimurium strain expressing Borrelia burgdorferi OspA prevents murine lyme borreliosis. Infect Immun 1995, 63: I6II-1614.

232. Agterberg $M$, Adriaanse $H$, Lankhof $H$, Meloen $R$, Tommassen J: Outer membrane PhoE protein of Escherichia coli as a carrier for foreign antigenic determinants: immunogenicity of epitopes of foot-and-mouth disease virus. Vaccine 1990, 8:85-91.

233. Luria-Perez R, Cedillo-Barron L, Santos-Argumedo L, Ortiz-Navarrete VF, Ocaña-Mondragon A, Gonzalez-Bonilla CR: A fusogenic peptide expressed on the surface of Salmonella enterica elicits CTL responses to a dengue virus epitope. Vaccine 2007, 25:50-7I.

234. Chinchilla M, Pasetti MF, Medina-Moreno S, Wang JY, Gomez-Duarte OG, Stout R, Levine MM, Galen JE: Enhanced immunity to Plasmodium falciparum circumsporozoite protein (PfCSP) by using Salmonella enterica serovar Thypi expressing PfCSP and a PfCSP-encoding DNA vaccine in a heterologous primeboost strategy. Infect Immun 2007, 75:3769-3779.

235. Daugherty PS, Olsen MJ, Iverson BL, Georgiou G: Development of an optimized expression system for the screening of antibody libraries displayed on the Escherichia coli surface. Prot Engineer 1999, 12:613-621.

236. Veiga E, de Lorenzo V, Fernandez LA: Structural tolerance of bacterial autotransporters for folded passenger protein domains. Mol Microbiol 2004, 52:1069-1080.

237. Ruiz-Olvera P, Ruiz-Perez F, Sepulveda NV, Santiago-Machuca A, Maldonado-Rodriguez R, Garcia-Elorriaga G, Gonzalez-Bonilla C: Display and release of the Plasmodium falciparum circumsporozoite protein using the autotransporter MisL of Salmonella enterica. Plasmid 2003, 50:12-27.

238. Charbit A, Molla A, Saurin W, Hofnung M: Versatility of a vector for expressing foreigner polypeptides at the surface of Gram-negative bacteria. Gene 1988, 70:181-189.

239. Francisco JA, Earhart CF, Georgiou G: Transport and anchoring of $\beta$-lactamase to the external surface of Escherichia coli. Proc Nat Acad Sci USA 1992, 89:2713-27I7.

240. Westerlund-Wikström B: Peptide display on bacterial flagella: principles and applications. Int J Med Microbiol 2000, 290:223-230.

24I. Kornacker MG, Pugsley AP: The normally periplasmic enzyme $\beta$-lactamase is specifically and efficiently translocated through the Escherichia coli outer membrane when it is fused to the cell-surface enzyme pullulanase. Mol Microbiol 1990, 4:II0I-II09.

242. Wong RSY, Wirtz RA, Hancock REW: Pseudomonas aeruginosa outer membrane protein OprF as an expression vector for foreign epitopes: the effects of positioning and length on the antigenicity of the epitope. Gene 1995, I 58:55-60.

243. Cote-Sierra J, Jongert E, Bredan A, Gautam DC, Parkhouse M, Cornelis $\mathrm{P}$, De Baetselier $\mathrm{P}$, Revets $\mathrm{H}$ : A new membrane-bound Oprl lipoprotein expression vector. High production of heterologous fusion proteins in gram (-) bacteria and the implications for oral vaccination. Gene 1998, 22 1:25-34.

244. Ruiz-Perez F, Leon-Kempis R, Santiago-Machica A, Ortega-Pierres G, Barry E, Levine M, Gonzalez-Bonilla C: Expression of the Plasmodium falciparum immunodominant epitope (NANP4) on the surface of Salmonella enterica using the autotransporter MisL. Infect Immun 2002, 70:36 I I-3620.

245. Zhu C, Ruiz-Perez F, Yang Z, Mao Y, Hackethal VL, Greco KM, Choy W, Davis K, Butterton JR, Boedeker EC: Delivery of heterologous protein antigens via hemolysin or autotransporter systems by an attenuated ler mutant of rabbit enteropathogenic Escherichia coli. Vaccine 2006, 24:382I-383I.

246. Veiga E, de Lorenzo V, Fernandez LA: Neutralization of enteric coronaviruses with Escherichia coli cells expressing singlechain Fv-autotransporter fusions. J Virol 2003, 77: I3396-I3398.

247. Wentzel A, Christmann A, Adams T, Kolmar H: Display of passenger proteins on the surface of Escherichia coli K-I 2 by the enterohemorragic $E$. coli intimin EaeA. J Bacteriol 2001, I 83:7273-7284.

248. Christmann A, Wentzel A, Meyer C, Meyers G, Kolmar H: Epitope mapping and affinity purification of monospecific antibodies by Escherichia coli cell surface display of gene-derived random peptide libraries. I Immunol Methods. 200I, 257(I2): $163-173$. 
249. Cavalieri S, Bohach G, Snyder I: Escherichia coli haemolysin: characteristic and probable role in pathogenicity. Microb Rev 1984, 48:326-343.

250. Koronakis V, Koronakis E, Hughes $\mathrm{C}$ : Isolation and analysis of the C-terminal signal directing export of Escherichia coli haemolysin protein across both bacterial membranes. EMBO J 1989 , 8:595-605.

25I. Gentschev I, Dietrich G, Goebel W: The E. coli alpha-haemolysin secretion system and its use in vaccine development. Trends Microbiol 2002, 10:39-45.

252. Fernandez LA, Sola I, Enjuanes L, de Lorenzo V: Specific secretion of active single-chain Fv antibodies into the supernatants of Escherichia coli cultures by use of the hemolysin system. Appl Environ Microbiol 2000, 66:5024-5029.

253. Fernandez LA, de Lorenzo V: Formation of disulfide bonds during secretion of proteins through the periplasmic-independent type I pathway. Mol Microbiol 200I, 40:332-346.

254. Fraile S, Muoz A, de Lorenzo V, Fernandez LA: Secretion of proteins with dimerization capacity by haemolysin type I transport system of Escherichia coli. Mol Microbiol 2004, 53: I I09- I I 2 I.

255. Sugamata $Y$, Shiba T: Improved secretory production of recombinant proteins by random mutagenesis of hlyB, an alphahemolysin transporter from Escherichia coli. Appl Environ Microbiol 2005, 7 I:656-662.

256. Lilie H, Schwarz E, Rudolph R: Advances in refolding of proteins produced in E. coli. Curr Opin Biotechnol 1998, 9:157-163.

257. Tsumoto K, Ejima D, Kumagai I, Arakawa T: Practical considerations in refolding proteins from inclusion bodies. Prot Expr Purif 2003, 28(I): I-8.

258. Vallejo LF, Rinas U: Strategies for the recovery of active proteins through refolding of bacterial inclusion body proteins. Microbiol Cell Factories 2004, 3(I): I I.

259. Rufdolph $\mathrm{R}$, Lilie $\mathrm{H}$ : In vitro folding of inclusion body proteins. Faseb J 1996, 10:49-56.

260. Bastings MM, van Baal I, Meijer EW, Merkx M: One-step refolding and purification of disulfide-containing proteins with a $C$-terminal MESNA thioester. BMC Biotechnol 2008, 8:76.

26I. Patil G, Rudolph R, Lange C: In vitro-refolding of a single-chain Fv fragment in the presence of heteroaromatic thiols. J Biotechnol 2008, I34:2I8-22I.

262. Tobbell DA, Middleton BJ, Raines S, Needham MR, Taylor IW, Beveridge JY, Abbott WM: Identification of in vitro folding conditions for procathepsin $\mathbf{S}$ and cathepsin $\mathbf{S}$ using fractional factorial screens. Prot Expr Purif 2002, 24(2):242-254.

263. De Bernardez Clark E, Schwarz E, Rudolph R: Inhibition of aggregation side reactions during in vitro protein folding. Methods Enzymol 1999, 309:217-236.

264. Mukhopadhyay A: Reversible protection of disulfide bonds followed by oxidative folding renders recombinant hCG $\beta$ highly immunogenic. Vaccine 2000, I8:1802-1810.

265. Cleland JL, Builder SE, Swartz JR, Winkler M, Chang JY, Wang DI: Polyethylene glycol enhanced protein refolding. Biotechnology 1992, 10:1013-1019.

266. Wetlaufer DB, Xie Y: Control of aggregation in protein refolding: a variety of surfactants promote renaturation of carbonic anhydrase II. Protein Sci. I995, 4(8): I535-I543.

267. Lu D, Liu Z: Dynamic redox environment-intensified disulfide bond shuffling for protein refolding in vitro: Molecular simulation and experimental validation. J Phys Chem B 2008, I I 2(47): 15 127-33.

268. Reiter Y, Schuck P, Boyd LF, Plaskin D: An antibody single-domain phage display library of a native heavy chain variable region: isolation of functional single-domain $\mathrm{VH}$ molecules with a unique interface. J Mol Biol 1999, 290:685-698.

269. Chen J, Liu Y, Wang Y, Ding H, Su Z: Different effects of Larginine on protein refolding: suppressing aggregates of hydrophobic interaction, not covalent binding. Biotechnol Prog 2008, 24:1365-1372

270. Gu Z, Weidenhaupt M, Ivanova N, Pavlov M, Xu B, Su Z-G, Janson J$\mathrm{C}$ : Chromatographic methods for the isolation of, and refolding of proteins from, Escherichia coli inclusion bodies. Prot Expr Purif 2002, 25: 174- 179.

27I. Veldkamp CT, Peterson FC, Hayes PL, Mattmiller JE, Haugner JC 3rd, de la Cruz N, Volkman BF: On-column refolding of recombinant chemokines for NMR studies and biological assays. Prot Expr Purif 2007, 52:202-209.
272. Stempfer G, Höll-Neugebauer B, Rudolph R: Improved refolding of an immobilized fusion protein. Nat Biotechnol. 1996, I4(3):329-334.

273. Langenhof M, Leong SS, Pattenden LK, Middelberg AP: Controlled oxidative protein refolding using an ion-exchange column. J Chromatogr 2005, 1069: 195-201.

274. Machold C, Schlegl R, Buchinger W, Jungbauer A: Continuous matrix assisted refolding of alpha-lactalbumin by ion exchange chromatography with recycling of aggregates combined with ultradiafiltration. J Chromatogr A 2005, I 080:29-42.

275. Chiku H, Kawai A, Ishibashi T, Takehara M, Yanai T, Mizukami F, Sakaguchi K: A novel protein refolding method using a zeolite. Anal Biochem 2006, 348:307-3।4.

276. Nara TY, Togashi H, Sekikawa C, Kawakami M, Yaginuma N, Sakaguchi $\mathrm{K}$, Mizukami $\mathrm{F}$, Tsunoda $\mathrm{T}$ : Use of zeolite to refold a disulfide-bonded protein. Colloids Surf B Biointerfaces 2009, 68:68-73.

277. Pigiet VP, Schuster BJ: Thioredoxin-catalyzed refolding of disulfide-containing proteins. Proc Natl Acad Sci USA 1986 83:7643-7647.

278. Lilie H, Lang K, Rudolph R, Buchner J: Prolyl isomerases catalyze antibody folding in vitro. Prot Sci 1993, 2:1490-1496.

279. Shin H-C, Scheraga HA: Catalysis of the oxidative folding of bovine pancreatic ribonuclease $A$ by protein disulfide isomerase. I Mol Biol 2000, 300:995-1003.

280. Ruoppolo M, Lundström-Ljung J, Talamo F, Pucci P, Marino G: Effect of glutaredoxin and protein disulfide isomerase on the glutathione-dependent folding of ribonuclease A. Biochemistry 1997, 36:12259-12267.

28I. Rancy PC, Thorpe C: Oxidative protein folding in vitro: a study of the cooperation between quiescin-sulphydryl oxidase and protein disulfide isomerase. Biochem 2009, 48:424-432.

282. Scholz $C$, Thirault L, Schaarschmidt $P$, Zarnt T, Faatz E, Engel AM, Upmeier B, Bollhagen R, Eckert B, Schmid FX: Chaperone-aided in vitro renaturation of an engineered $E I$ envelope protein for detection of anti-Rubella virus IgG antibodies. Biochemistry. 2008, 47( I 4):4276-4287.

283. Altamirano MM, Garcia C, Possani LD, Fersht AR: Oxidative refolding chromatography: folding of the scorpion toxin Cn5. Nat Biotech 1999, 17:187-191.

284. Tsumoto K, Umetsu M, Yamada H, Ito T, Misawa S, Kumagai I: Immobilized oxidoreductase as an additive for refolding inclusion bodies: application to antibody fragment. Protein Eng 2003, 16:535-54I.

285. Morjana NA, Gilbert HF: Catalysis of protein folding by agaroseimmobilized protein disulfide isomerase. Prot Expr Purif 1994, 5: $144-148$.

286. Ying BW, Taguchi $\mathrm{H}$, Ueda $\mathrm{H}$, Ueda $\mathrm{T}$ : Chaperone-assisted folding of a single-chain antibody in a reconstituted translation system. Biochem Biophys Res Commun 2004, 320: I 359-I 364.

287. Buchner J, Brinkmann U, Pastan I: Renaturation of a single-chain immunotoxin facilitated by chaperones and protein disulfide isomerase. Biotechnology 1992, 10:682-685.

288. Nian R, Tan L, Yoo IK, Choe WS: Chaperone-assisted column refolding of gloshedobin with the use of refolding cocktail. Chromatogr A 2008, 12 I 4:47-58.

289. Seefeldt MB, Ouyang J, Froland WA, Carpenter JF, Randolph TW: High-pressure refolding of bikunin: efficacy and thermodynamics. Protein Sci 2004, I 3:2639-2650.

290. de Marco A: Minimal information: an urgent need to assess the functional reliability of recombinant proteins used in biological experiments. Microb Cell Fact 2008, 7:20.

29I. Buckle AM, Devlin GL, Jodun RA, Fulton KF, Faux N, Whisstock JC, Bottomley SP: The matrix refolded. Nature Meth 2005, 2:3. 